\title{
PROBLEMATYKA MORALNA W STULETNIEJ (1920-2020) HISTORII „COLLECTANEA THEOLOGICA”
}

Komitet redakcyjny nowego pisma teologicznego, „Przeglądu Teologicznego” (później „Collectanea Theologica”), założonego w Lwowie w 1920 r., w Naszym programie napisał, że zamierza stworzyć kwartalnik, w którym będą mogli publikować księża pracujący naukowo. Pismo miało się oprzeć na pięciu polskich wydziałach teologicznych, przede wszystkim na współpracy trzech Uniwersytetów: Lwowskiego, Jagiellońskiego i Warszawskiego. Treść poszczególnych zeszytów miała składać się z trzech części: 1. artykułów i rozpraw wstępnych, oceny podręczników oraz materiałów badawczych; 2. rozpraw oryginalnych; 3. recenzji i sprawozdań. Celem czasopisma było publikowanie artykułów i rozpraw badawczych ze wszystkich gałęzi teologicznych, ,poczynając na Piśmie św., a kończąc na homiletyce”, 2 w tym teologii moralnej. Od rozpoczęcia II wojny światowej do 1949 r. „Collectanea Theologica” nie ukazywała się. W 1949 r. wznowiono wydawanie czasopisma po przeniesieniu siedziby redakcji z Lwowa do Warszawy i odtąd, z wyjątkiem przerwy w 1966 r., kwartalnik ukazuje się nieprzerwanie do chwili obecnej.

Teologia moralna oparta na objawieniu Bożym poszukuje praktycznych odpowiedzi na pytanie: Co powinniśmy czynić? W jej

1 Kwartalnik naukowy „Przegląd Teologiczny” od 1931 r. ukazywał się pod nowym tytułem „Collectanea Theologica” W podsumowaniu dotychczasowej działalności „Przeglądu Teologicznego” wspomniano o przyszłych planach czasopisma naukowego, aby jakaś część artykułów mogła ukazywać się w obcych językach oraz aby dodawać streszczenia w języku łacińskim czy francuskim.

2 Nasz Program, Przegląd Teologiczny 1/1920, s. 4. 
historii odkrywamy przemiany świadomości moralnej ludzi, zależnych od wielu czynników społeczno-politycznych i gospodarczych, a przede wszystkim od rozumienia i interpretacji przesłania Ewangelii. Wieloletni redaktor Biuletynu teologicznomoralnego napisał, że rozwój teologii moralnej ,zależał zarówno od ogólnych tendencji w całej teologii, w życiu Kościoła, jak i od kierunków panujących w kulturze i filozofii oraz od stosunków społeczno-politycznych danego okresu". ${ }^{3}$ W powyższe uwarunkowania wpisuje się kwartalnik „Collectanea Theologica”, w którym podejmowano aktualne wyzwania i problemy. Sto lat historii czasopisma naukowego jest dobrą okazją do zbadania treści publikowanych artykułów, rozpraw czy sprawozdań i omówień z zakresu teologii moralnej w zmieniającej się sytuacji społecznej w Polsce, jak też w świetle zainicjowanych i wdrażanych reform II Soboru Watykańskiego. Zatem szczegółowa analiza twórczości teologów moralistów publikujących w „Collectanea Theologica" pokazuje ich sposób badań i metody w podejściu do ważnych zagadnień moralnych, będących odbiciem ówczesnych wyzwań społecznych i kościelnych w Polsce.

Problematyka teologii moralnej jest rozważana w perspektywie interdyscyplinarnej, przede wszystkim na gruncie nauk teologicznych, takich jak: patrologia, egzegeza biblijna, teologia życia duchowego czy prawo kanoniczne. Natomiast spośród nauk nieteologicznych bliskie teologii moralnej są etyka filozoficzna oraz nauki empiryczne, do których należy zaliczyć: psychologię, medycynę, socjologię i ekonomię. Łączność powyższych dziedzin naukowych z teologią moralną została uwydatniona w licznych artykułach i rozprawach ukazujących się najpierw w „Przeglądzie Teologicznym”, a później w „Collectanea Theologica". Zatem w zróżnicowanej problematyce teologii moralnej można wskazać osiem podstawowych nurtów i obszarów badawczych, które zostaną omówione w niniejszej pracy w następującej

3 J. Pryszmont, $Z$ historii teologii moralnej w ostatnich wiekach. Kierunki odnowy, Studia Theologica Varsaviensia 1/1983, s. 49. J. Pryszmont redagował Biuletyn teologicznomoralny wydawany w „Collectanea Theologica” w latach 1967-1987. 
kolejności tematycznej: historyczno-moralna, biblijno-moralna, filozoficzno-moralna, psychologiczno-moralna, pastoralno-moralna, katolicka nauka społeczna, biomedyczno-moralna i kwestia odnowy teologii moralnej. Zebrany materiał zawiera krótkie i zwięzłe omówienia wszystkich artykułów, opublikowanych w czasopiśmie naukowym „Collectanea Theologica” od 1920 do 2019 r., w których autorzy poruszali zagadnienia moralne. Poszczególne streszczenia rozpraw zostały umieszczone w osobnych blokach tematycznych i przedstawione w porządku chronologicznym.

Merytorycznym dodatkiem w czasopiśmie naukowym „Collectanea Theologica" był Biuletyn teologicznomoralny składający się najczęściej z trzech działów: dokumenty Kościoła katolickiego, sprawozdania i komunikaty (będące relacją z licznych z konferencji i sympozjów naukowych organizowanych zarówno w Polsce, jak i zagranicą) oraz recenzje i omówienia nowych publikacji.

\section{Tematyka historyczno-moralna}

Ten blok tematyczny obejmuje fundamentalne zagadnienia moralne dotyczące dawnej praktyki chrześcijańskiej odnośnie do spowiedzi, dyscypliny pokutnej, postów czy odpustów. Autorzy publikacji naukowych często też odwoływali się do nauki Ojców Kościoła, przede wszystkim do św. Augustyna i św. Tomasza. W poszczególnych rozprawach omówili dawne rozwiązania w świetle chrześcijańskiej tradycji moralnej, w takich kwestiach jak: grzech, sumienie oraz sakramenty. Na szczególną uwagę zasługują gruntowne i wyczerpujące opracowania M. Sieniatyckiego, L. Wasilkowskiego, A. Kalickiego i J. Pryszmonta, które ze względu na dużą objętość były drukowane w kilku częściach lub w kilku numerach czasopisma.

Już od piątego numeru „Przeglądu Teologicznego” (1921 r. z. 1) rozpoczął się cykl rozpraw wstępnych autorstwa M. Sieniatyckiego na temat: Pokuta kościelna wedtug Ojców Zachodnich (s. 33-39). W pierwszym artykule autor przedstawił główne założenia dawnej pokuty kościelnej (aż do końca IV w.). Proces pokuty opisał w następujących punktach: 1. wyznanie grzechów przed biskupem lub 
kapłanem mające charakter spowiedzi publicznej; 2. mowa biskupa lub kapłana uzasadniająca potrzebę publicznej pokuty (karcenie i zachęta, a nawet ostrzeżenie przed ekskomuniką); 3. pokuta publiczna lub tajna jako zadośćuczynienie; 4. rozgrzeszenie i uroczyste pojednanie grzesznika z Kościołem.

Powyższą problematykę Sieniatycki kontynuował w następnych zeszytach do końca 1921 r. (z. 2, s. 147-160 i z. 3-4, s. 213-236; łącznie artykuł liczył 42 stronice). Następnie w 1922 r., w z. 4 (s. 273-289), rozwiną temat pokuty w artykule Spory na Zachodzie o dyscypline pokutna. Omówił dwa poważne konflikty dotyczące praktyki pokutnej w czasach papieży Kaliksta i Cypriana ( $† 258)$, które przyczyniły się do wydania dekretu, pozwalającego odpuszczać grzechy pokutującym cudzołożnikom. Drugi dotyczył lapsi, którzy w czasach prześladowań Decjusza zaparli się wiary przez składanie bogom ofiar ekspiacyjnych w państwie rzymskim. Według autora artykułu w tym przypadku chodziło o ustalenie warunków ponownego przyjęcia do Kościoła. Ustalono, że jedynie umierających, zarazem podejmujących pokutę, można przywrócić ponownie do Kościoła, zaś o pozostałych miał rozstrzygać biskup. Problem był tym bardziej aktualny, że dotyczył licznej rzeszy upadłych. Ostatecznie postanowiono na synodzie w Kartaginie w 251 r., aby czyniących pokutę na nowo do Kościoła przyjąć.

Następnie L. Wasilkowski w artykule Nauka Cypriana z Kartaginy o kapłaństwie $w$ zestawieniu z tradycja pierwszych trzech wieków. Studium historyczno-dogmatyczne (1923 r. z. 1) omówił powyższy temat z zaznaczeniem aspektów moralnych (np. w rozdziale trzecim opisuje skutki kapłańskiego działania w dziedzinie sakramentów św.). Podstawą do badań zadań kapłana były dzieła św. Cypriana. Według autora artykułu „duchowny przedstawiony jest głównie, jako człowiek posiadający znajomość słowa Bożego, którego obowiązkiem jest być mężem modlitwy" (s. 12). Podkreślił też, że ,przepis dany w Starym Zakonie, by kapłani byli świętymi, trwa i dziś w swej mocy - jeśli uchybią - będą odtrąceni przez Boga i starania ich próżne będą" (s. 26). Wasilkowski w następnym zeszycie (z. 2) tego roku kontynuował powyższy temat. 
Z kolei W. Wicher przedstawił postać Mikołaja z Mościsk, teologa moralisty i pisarza ascetycznego z XVII w., który tworzył zarówno dzieła kazuistyczne, jak i teologiczno-moralne (Mikołaj z Mościsk. Teolog moralista i pisarz ascetyczny z początku XVII w., s. 209-225). Wicher zajął się badaniem traktatu Mikołaja z Mościsk Elementa ad Confessiones z 1610 r., wielokrotnie wówczas publikowanego. Według autora publikacji Mikołaj pisał w nim m.in. o zasadach odnoszących się do spowiadania i przyjmowania Komunii św. przez wiernych.

W kolejnym roku (1930) należy wskazać rozprawę z zakresu historii teologii moralnej L. Halbana Społeczno-polityczne wskazania św. Augustyna (s. 491-523), w której zawarto przesłanie moralne na temat prawidłowego funkcjonowania państwa. Autor badał w niej implikacje moralne, opierając się na dziele św. Augustyna De Civitate Dei.

W 1931 r. A. Kalicki opublikował w dwóch częściach obszerny artykuł pod tytułem: Posty w dawnej Polsce (s. 190-235 oraz 299-380) mający charakter historyczno-moralny. Autor na początku rozprawy określił cel postów i umartwień, które miały służyć osiągnięciu doskonałości chrześcijańskiej. Kwestię postów badał w Polsce od drugiej połowy X w., czyli od przyjęcia chrześcijaństwa. Zaznaczył, że o formach postu decydowały wówczas ustawy synodalne i statuty biskupie. W czasie postu nie jedzono mięsa, a także nabiału i jaj (chodziło o produkty pochodzenia zwierzęcego). „I kogo schwycą jedzącego mięso (...) ciężko bywa karany wybiciem zębów" (s. 202). Kalicki przypomniał, że poszczono także w okresie Adwentu, który był znacznie łagodniejszy. Od XIII w. ten post zaczął zanikać, a pozostała tylko praktyka postu adwentowego w wigilię Bożego Narodzenia.

W 1935 r. Z. Goliński, w artykule Nauka Jana Kasjana o kłamstwie użytecznym (s. 491-503), omówił jeden z klasycznych problemów teologii moralnej dotyczący kłamstwa. Na początku autor wyjaśnił, że kłamstwo użyteczne ma miejsce wówczas, gdy mówi się nieprawdę w celu osiągnięcia pewnej korzyści, jednocześnie nikomu nie szkodząc. W świetle nauki Jana Kasjana, działającego na przełomie IV i V w., Goliński poszukiwał pewnych racji uzasadniających użycie kłamstwa użytecznego. Podkreślił, że Kasjan tłumaczył 
kłamstwo użyteczne jako uwarunkowane krańcową potrzebą. Według autora artykułu tego typu kłamstwo Kasjan nazywał kłamstwem dopuszczalnym i zaliczał je do grzechów lekkich. Następnie ocenił koncepcję Kasjana w świetle nauki św. Augustyna, który z kolei uważał, że nie można usprawiedliwiać kłamstwa użytecznego. Na koniec stwierdził, że Kościół katolicki opowiada się za argumentacją św. Augustyna, czyli przeciwko Kasjanowi.

W artykule Pokuta chrześcijańska wedtug Konstytucji Paenitemini (1967 r. z. 1, s. 113-123) J. Pryszmont nawiązał do ostatnio ogłoszonej uchwały soborowej odnośnie do powyższego tematu. Przypomniał, że 17 lutego 1966 r. papież Paweł VI ogłosił Konstytucję apostolską Paenitemini, w której podał nowe instrukcje dotyczące zachowywania postu. Autor artykułu najpierw omówił praktykę pokutną w Biblii, zarówno w Starym, jak i Nowym Testamencie. Następnie na podstawie Konstytucji przedstawił istotę i aktualne zalecenia Kościoła w praktykowaniu pokuty. W podsumowaniu stwierdził, że ,,autentyczna pokuta stanowi drogę odnowy i naprawy, której ludzkość, według słów Konstytucji, stale potrzebuje" (s. 122).

W z. 2 z 1967 r. J. Bar w artykule Nowe zasady korzystania z odpustów (s. 97-104) najpierw przedstawił krótki rys historii odpustów, a następnie podał ich definicję i znaczenie do zbawienia chrześcijan. Napisał m.in.: „Odpust jest to uchylenie wobec Boga kary doczesnej za grzechy zgładzone już co do winy, którego wierny - odpowiednio usposobiony, przy zachowaniu pewnych określonych warunków dostępuje za sprawą Kościoła” (s. 98). Potem zajął się omówieniem znaczenia zarówno odpustu cząstkowego, jak i zupełnego w świetle nowego dokumentu o odpustach Indulgentarium doctrina z $1967 \mathrm{r}$. Autor artykułu przypomniał też warunki otrzymania odpustu zupełnego i cząstkowego, do których zaliczył: uwolnienie się od przywiązania do grzechu, wykonanie określonej czynności związanej z odpustem (np. nawiedzenie Kościoła), spowiedź, Komunię św. i modlitwę w intencji papieża. W podsumowaniu J. Bar zaznaczył, że w zależności od wykonania wszystkich lub jedynie niektórych powyższych warunków odpust może być zupełny lub częściowy. 
W kolejnym zeszycie „Collectanea Theologica” A. Nossol opisał Grzech pierworodny w teologii protestanckiej (1972 r. z. 3, s. 5-26). Autor przedstawił historyczny zarys idei grzechu pierworodnego w świetle wypowiedzi przedstawicieli protestantyzmu: Marcina Lutra, Ulryka Zwingliego i Jana Kalwina. Najpierw nawiązał do Konfesji augsburskiej, w której znajdował się wykład o skutkach grzechu pierworodnym w rozumieniu protestanckim. Czytamy w niej m.in., że ,po upadku Adama wszyscy ludzie rodzący się w naturalny sposób, bywają poczęci i rodzą się w grzechu" (s. 10).

$\mathrm{Z}$ kolei F. Scholz w artykule Prawa sumienia religijnego $w$ dziejach Kościoła (1974 r. z. 3, s. 5-18) omówił historię praw sumienia w aspekcie moralnym, nawiązując do deklaracji soborowej z 7 grudnia 1965 r. na temat wolności sumienia. Napisał we wstępie, że „W świetle faktów zobaczymy, jak traktowano prawa sumienia i jak przebiegał rozwój wskazań doktrynalnych" (s. 6). Rozprawa Scholza jest pracą historyczno-moralną pokazującą Kościół, który bronił w różnych epokach wolności religijnej wiernych.

Następnie J. Pryszmont omówił specyfikę teologii moralnej Kościoła prawosławnego w artykule zatytułowanym Prawosławna teologia moralna (1975 r. z. 2, s. 35-52). Autor na początku artykułu napisał, że w etyce prawosławnej znajdujemy ,pewne wartości, które mogą okazać się cenne w pracach nad udoskonaleniem katolickiej teologii moralnej" (s. 35). Pryszmont analizował proces kształtowania się nauki moralnej w Rosji od przyjęcia chrześcijaństwa w Bizancjum (989 r.), aż po czasy mu obecne. Zauważył, że na formowanie się prawosławnej moralności miał wpływ nie tylko nurt ascetyczno-mistyczny w Rosji, ale także katolicyzm (Kijowska Szkoła Teologiczna), a nawet protestantyzm (podręczniki teologii moralnej wzorowały się na autorach protestanckich). Autor stwierdził, że prawosławna teologia moralna opiera się przede wszystkim na Piśmie Świętym Nowego Testamentu oraz tradycji. Dodał, że w odróżnieniu od katolickiej teologii moralnej w prawosławiu nie przypisywano większej roli filozofii ani prawu. Według Pryszmonta prawosławna teologia moralna, wzorując się na pismach świętych ascetów, odznacza się 
mistycznym charakterem, a także nie zawiera skomplikowanych traktatów moralnych czy szczegółowych wskazań moralnych.

Jan Pryszmont w kolejnym artykule zatytułowanym Nawrócenie jako odpowiedź człowieka na zbawcze dzieło Chrystusa (1984 r. z. 2, s. 17-29) omówił sytuację moralną wiernych w perspektywie Roku Jubileuszowego. Zwrócił uwagę, że od czasów wczesnego chrześcijaństwa zaszły negatywne zmiany w praktyce pokutnej Kościoła. Zaliczył do nich m.in. zanik poczucia grzechu i osłabienie poczucia winy moralnej, wykonywanie w sposób symboliczny pokuty i łatwość w uzyskaniu ogólnego rozgrzeszenia. Pryszmont stwierdził, że współczesnemu człowiekowi potrzebna jest pogłębiona wizja nawrócenia, pokuty i pojednania. Przypomniał, że Chrystus zawsze „nawoływał do nawrócenia, ponieważ jest ono warunkiem koniecznym urzeczywistnienia zbawienia" (s. 21). Według autora artykułu chodzi o przemianę wewnętrzną, zerwanie z grzechem i wytrwałą pracę nad kształtowaniem cnót moralnych.

Tematykę sakramentu pokuty również podjął Z. Sareło w artykule Kapłan jako spowiednik (1988 r. z. 1, s. 41-56), zainspirowany adhortacją apostolską Jana Pawła II Reconciliatio et paenitentia. Napisał, że ,źródłem licznych zarzutów stawianych spowiedzi i jedną z głównych przyczyn niechętnego jej praktykowania są nazbyt często spotykane niewłaściwe postawy spowiedników wobec penitentów, bądź też pewne braki w umiejętności sprawowania tego sakramentu" (s. 41). Autor na początku artykułu opisał dwa zadania spowiednika: sędziego i lekarza, jednocześnie zalecając ten drugi sposób wykonywania spowiedzi przez duchownych. Sareło przypomniał, że kapłan jako sługa i narzędzie przebaczającego Boga powinien odnosić się do grzesznika z miłością i czułością. Dlatego krytykował zbyt jurydyczne podejście spowiedników do penitentów, które ugruntowało się jeszcze w czasach przedsoborowych. Według autora publikacji spowiednik jako duchowy lekarz ma zadanie pomagać grzesznikowi w odkrywaniu dróg pokuty i nawrócenia. Przejawem skuteczności, a zarazem pomocy spowiednika będzie doprowadzenie grzesznika do uznania winy i wzięcia odpowiedzialności za skutki popełnionego grzechu. 
W następnym zeszycie „Collectanea Theologica” wydanym w tym samym roku Z. Perz w artykule Pokuta i Eucharystia w zwiazku z Synodem Biskupów 1983 (1988 r. z. 2, s. 29-37) omówił aktualną naukę Kościoła w odniesieniu do pokuty i Eucharystii. Autor zwrócił uwagę na związki pokuty z Eucharystią, dzięki którym możliwy jest osobowy kontakt wierzącego z Chrystusem. Napisał, że „Eucharystia stanowi w Kościele szczyt pojednania z Bogiem i ludźmi” (s. 31). Przypomniał też, że już Sobór Trydencki nauczał, iż Eucharystia odpuszcza winy powszednie i chroni przed ciężkimi. Perz podkreślił, że pokuta włącza grzesznika do społeczności Kościoła, a przede wszystkim do wspólnoty Eucharystii.

W 1989 r. w z. 3 J. Królikowski w krótkim artykule Bierzmowanie jako sakrament duchowej otwartości $w$ refleksji św. Tomasza z Akwinu (s. 45-49) zajął się jednym z sakramentów chrześcijańskich w świetle nauki św. Tomasza. Zatem przypomniał rozumienie sakramentu bierzmowania w świetle nauki Akwinaty.

Z kolei J. Bramorski w artykule zatytułowanym Moralność chrześcijańska jako życie w Duchu Świętym (2006 r. z. 3 s. 33-52) rozważał zagadnienia moralności w świetle działania Ducha Świętego. Napisał, że ,centralnym tematem teologii moralnej jest wyzwalające działanie Ducha Świętego" (s. 37). Według autora chodziło o zmianę postrzegania teologii moralnej, która dawniej zbytnio skupiała się na grzechu, a za mało była otwarta na pokazanie wyzwalającego działania Boga. Inspiracją w podjętych rozważaniach Bramorskiego była Suma teologiczna św. Tomasza, w której w odniesieniu do moralności, jak zaznaczył autor, istotną rolę odgrywają cnoty i łaska Boga.

W 2010 r. w z. 3 M. Mróz w artykule Charakter sakramentalny a uczestnictwo wiernych w oddawaniu czci Bogu: kilka uwag na kanwie nauki św. Tomasza z Akwinu o Conformitas Christi (s. 35-53) poruszył kwestię upodobnienia chrześcijanina do Chrystusa, opartego na łaskach płynących z przyjmowania sakramentów świętych. Autor artykułu, odwołując się do myśli św. Tomasza, wskazał nierozerwalny związek sakramentów z moralnością w życiu chrześcijanina.

W kolejnym artykule Nauka św. Marka Eremity o cnocie W. Patrin (2019 r. z. 1, s. 89-100) na początku wyjaśnił znaczenie cnoty, 
nawiązując do klasycznego modelu czterech cnót: mądrości, męstwa, umiarkowania i sprawiedliwości. Następnie wskazał nowe cnoty w ujęciu św. Marka Eremity, takie jak: dzielność ducha, pokorę, czujność i wstrzemięźliwość, które pozwalały skuteczniej realizować chrześcijańską doskonałość. Patrin w dalszej części artykułu stwierdził, że św. Marek używał cnoty w zależności od konkretnej sytuacji moralnej. W podsumowaniu napisał, że „w innym przypadku, mówiąc o nawróceniu, św. Marek zaznacza trzy cnoty: oczyszczenie myśli, nieustanną modlitwę i cierpliwe znoszenie spotykających nas przykrości” (s. 93).

Także w tym numerze (2019 r. z. 1) znalazł się jeszcze jeden artykuł o tematyce moralnej, autorstwa L. Nieściora, zatytułowany Namiętności $i$ walka $z$ nimi wedtug Marka Eremity (s. 101-114). Autor na początku zwrócił uwagę, że niewiedza dotycząca namiętności prowadzi do upadku oraz że uleganie namiętnościom jest przejawem choroby moralnej. Podkreślił, opierając się na myśli św. Marka Eremity, że namiętności takie jak: chciwość, próżność i rozkosz są ze sobą powiązane. Zaznaczył też, że „namiętności są postaciami zła rozlewającymi się we wnętrzu serca” (s. 105). W dalszej części artykułu autor opisał różne sposoby walki z namiętnościami według św. Marka Eremity. W zakończeniu Nieścior podkreślił, że zamiast ulegać namiętnościom, należy ćwiczyć się w cnocie, zaś pomocniczymi środkami w zwalczaniu namiętności są pokuta i medytacja.

\section{Tematyka biblijno-moralna}

Kolejny obszar badawczy w „Collectanea Theologica” obejmuje problematykę biblijno-moralną. Prace naukowe biblistów, którzy zajmują się interpretacją treści biblijnych, są szczególnie cenne, gdyż wyniki ich badań mogą posłużyć do opracowania komentarzy i refleksji teologicznej, także w zakresie teologii moralnej. Należy podkreślić, że w czasie obrad II Soboru Watykańskiego zwracano uwagę na potrzebę odnowy teologii, w tym teologii moralnej. Postulowano, aby, opierając się na Piśmie Świętym Starego i Nowego Testamentu, rozwiązywać kwestie moralności chrześcijańskiej. W dokumencie 
soborowym napisano, że „szczególną troskę należy skierować ku udoskonaleniu teologii moralnej, której naukowy wykład, karmiony w większej mierze nauką Pisma św., niech ukazuje wzniosłość powołania wiernych w Chrystusie i ich obowiązek przynoszenia owocu w miłości dla życia świata" (Dekret o formacji kapłańskiej Optatam Totius nr 16). Zatem Sobór zachęcał, aby przesłanie moralne interpretować w świetle egzegezy i teologii biblijnej. Artykuły omówione poniżej są dobrym przykładem ubiblijnienia teologii moralnej. $\mathrm{Na}$ szczególną uwagę zasługują prace biblijno-moralne L. Stachowiaka, H. Muszyńskiego i W. Chrostowskiego.

W artykule Pouczenia etyczne w literaturze międzytestamentalnej (1978 r. z. 3, s. 43-62) L. Stachowiak badał kształtowanie się napomnień moralnych zarówno w Starym jak i Nowym Testamencie. Na ten temat napisał, że ,ideał moralny pouczeń, wyrażający się szczególnie w etyce pobożności i miłości bliźniego, odcina się wyraźnie od dotychczasowych wskazań etycznych rytualno-prawnych w Starym Testamencie" (s. 51). Autor artykułu dostrzegał wyraźne różnice w literaturze biblijnej Starego i Nowego Testamentu odnośnie do konkretnych wymogów moralnych, zmieniających się w zależności od uwarunkowań społeczno-historycznych Izraela. Mimo powyższych trudności Stachowiak podkreślał nieustanny rozwój zasad moralnych w Starym Testamencie, które dopiero w Jezusie Chrystusie znalazły swoje dopełnienie.

W kolejnym zeszycie pisma H. Muszyński w artykule Bóg a zło w Piśmie Świętym (1979 r. z. 2, s. 23-48) zajął się problemem zła w perspektywie biblijnej. Autorowi chodziło przede wszystkim o zbadanie pochodzenia zła, jego natury i istoty. Na początku rozprawy postawił ważne pytanie: „Co wnosi Biblia do oświetlenia problemu zła i do przezwyciężenia rzeczywistości zła istniejącego w świecie?” (s. 23). W odpowiedzi Muszyński zaznaczył, że w Biblii nie znajdujemy w pełni zadowalającego rozwiązania tej kwestii. Zauważył, że zło nie jest też jedynie brakiem dobra, jak w historii głosili św. Augustyn czy św. Tomasz z Akwinu. Autor artykułu wyjaśnił, że w świetle tekstów biblijnych zło jawi się jako dynamiczna, destrukcyjna siła, która zniewala człowieka i powoduje różnorakie zniszczenia. Dodał 
też, że Bóg może dopuszczać lub nawet zsyłać pewne zło na grzeszników w postaci kary, ale takie działania mają charakter pedagogiczny. Według Muszyńskiego Bóg w ten sposób chce uświadamiać grzesznikowi wagę złego czynu. Autor artykułu podkreślił, że jedynie Bóg może człowieka ocalić i zbawić od wszelkiego zła.

Następnie L. Stachowiak w artykule Badania nad napomnieniami moralnymi św. Pawła wXX wieku (1983 r. z. 2, s. 47-64) zajął się oceną aktualności wskazań moralnych św. Pawła. Autor podkreślił, że przesłanie moralne św. Pawła służyło bardziej skutecznemu głoszeniu Dobrej Nowiny o Chrystusie. Stachowiak napisał, że ,pouczenia etyczne listów Pawłowych nawiązują w swej treści do odnośnych wyobrażeń starotestamentalnych i judaistycznych" (s. 48).

W kolejnym numerze W. Chrostowski w artykule Rachunek sumienia Ludu Bożego na przykładzie Ne 9, 6-37 (1990 r. z. 4, s. 5-17) zajął się egzegezą biblijną modlitwy Ezdrasza z Księgi Nehemiasza, w której znajduje się pewne przesłanie moralne. Według autora publikacji, analizując etapy tworzenia się zaznaczonego w tytule tekstu trzeba zwrócić uwagę na drugą część modlitwy Ezdrasza (ww. 32-37), w której zawarte jest wyznanie grzechów Izraela i prośba o ich odpuszczenie. Jak napisał autor artykułu: „Dominuje myśl, że mamy do czynienia z wyznaniem win i prośbą o przebaczenie" (s. 7). Chrostowski opisał też terminy pokutne, które obrazowały relacje Boga ze swoim ludem.

W 2001 r. K. Kietliński w artykule Podstawy zobowiąań moralnych Izraela w nauczaniu proroków z VIII w. przed Chr. (z. 4, s. 25-38), badał kwestie moralne w ujęciu czterech proroków: Amosa, Ozeasza, Izajasza i Micheasza, przedstawicieli państwa północnego i południowego. Autor napisał, że prorocy „opierając się na starych tradycjach, przypominali narodowi jego moralne powinności” (s. 26). Autor rozprawy opracował wyzwania moralne ówczesnego Izraela w perspektywie wybrania, przymierza i prawa starotestamentalnego.

Franciszek Mickiewicz, w artykule Znaczenie sumienia oraz prawa wypisanego w sercu wedtug $R z$ 2, 12-16 (2013 r. z. 2, s. 77-96), zajął się problemem przestrzegania prawa, a usprawiedliwieniem na przykładzie wybranego tekstu św. Pawła. Zwrócił uwagę na znaczenie 
sumienia w rozwiązaniu powyższej kwestii. Autor napisał, że „prawo, które do tej pory było traktowane jako narzucone z góry, będzie ściśle zespolone z intelektualnym, wolitywnym i emocjonalnym centrum człowieka i od wewnątrz będzie kierowało całym jego życiem” (s. 90).

\section{Tematyka filozoficzno-moralna}

Problematyka filozoficzno-moralna wydaje się jedną z najważniejszych i najczęściej poruszanych nie tylko w teologii. Od czasów starożytnych poszukiwano źródeł pouczeń moralnych, czego przejawem były pytania dotyczące znaczenia takich pojęć jak „wolność”, „prawda”, „dobro” i ,zło”, „sumienie”, ,,prawo” czy „norma”. Powyższe dylematy są wyzwaniem także dla teologii moralnej, która próbuje określić powinności moralne w świetle objawienia czy tradycji Kościoła. Na ten temat w jednym z dokumentów II Soboru Watykańskiego czytamy, że „w głębi sumienia człowiek odkrywa prawo, którego sam sobie nie nakłada, lecz któremu winien być posłuszny i którego głos wzywający go zawsze tam, gdzie potrzeba, do umiłowania i czynienia dobra a unikania zła, rozbrzmiewa w sercu nakazem: czyń to, tamtego unikaj" (Konsty tucja duszpasterska Gaudium et spes, nr 16). Do ważnych przedstawicieli (zarówno polskich, jak i zagranicznych) tego działu należy zaliczyć: J. Woronieckiego, S. Rosika, T. Ślipkę, J. Salija, M. Gogacza, oraz B. Häringa, K. Böcklego i G. Zieglera.

Witold Rubczyński w 1926 r. napisał artykuł zatytułowany $W$. R. Sorleya teoria wartości moralnych oraz jej związek z jego ogólnym poglądem na świat, w którym badał warunki powodzenia działania ludzkiego. Zajął się podstawami moralnymi w budowaniu ładu indywidualnego i społecznego, podkreślając, że moralnie dobre jest takie działanie, które prowadzi do konsolidacji wspomnianych porządków. Powyższą tematykę opublikował w czterech artykułach, w ciągu dwóch lat ukazywania się „Przeglądu Teologicznego” (1926 i 1927, s. 1-48, 148-195, 282-312 i 369-428). Podstawą do badań było dzieło W. R. Sorleya zatytułowane Życie moralne i moralna wartość z $1911 \mathrm{r}$. 
Kolejnym autorem, który podjął tematykę moralną, był J. Woroniecki. W rozprawie zatytułowanej Moc i wartość spekulatywnych cech tomizmu (1927 r. w z. 1, s. 39-41) zajął się obroną twórczości filozoficzno-moralnej św. Tomasza z Akwinu. Myślą przewodnią artykułu Woronieckiego był cytat pochodzący od św. Tomasza, że „tyle ma każdy cnoty, ile ma inteligencji” (s. 39). Autor powołał się na drugą część Sumy teologicznej, akcentując wartość i aktualność metody kazuistycznej w teologii moralnej. W uzasadnieniu napisał, że ,teologia spekulatywna nie jest niczym innym, jak analitycznym badaniem prawd wiary, aby zeń potem syntetycznie budować normy postepowania" (s. 39).

Podobnie w następnym roku (1928) A. Gmurowski w artykule Podwójna podstawa obowiązku dążenia do doskonałości wedtug $s ́$ w. Tomasza (s. 167-183) analizował perfekcjonizm etyczny w ujęciu św. Tomasza. Autor przedstawił kwestię wypełnienia powołania chrześcijan do życia w doskonałości w podwójnym kluczu, a mianowicie jako drogę opartą na przestrzeganiu dziesięciu przykazań lub realizacji ośmiu rad ewangelicznych. Na ten temat napisał m.in.: „Prawo rozumu i prawo miłości - to dwa bieguny tomistycznej teologii moralnej (...) doskonałość bowiem przyrodzona nie istnieje samodzielnie obok doskonałości nadprzyrodzonej; prawo rozumu, oświecone nadprzyrodzonymi cnotami wiary i roztropności i darem rady, wstępuje na poziom miłości Bożej” (s. 169).

Kolejną publikacją z 1928 r. na styku filozofii i teologii moralnej był artykuł Aleksandra Żychlińskiego zatytułowany: Nauka św. Tomasza z Akwinu o naturze łaski działającej (s. 347-366), w którym autor opisał znaczenie łaski Bożej i cnót w życiu chrześcijanina. Zatem w perspektywie nauki św. Tomasza rozważał naturę i sposoby działania łaski Bożej w duszy człowieka.

W 1929 r. Stanisław Narajewski w artykule Akty moralnie dobre (s. 10-24) badał problematykę dobra i zła moralnego. Według autora w ocenie aktów ludzkich moralnie dobrych lub złych decyduje przede wszystkim wolność działającego podmiotu. Podkreślił, że człowiek może podejmować samodzielnie dobre lub złe decyzje moralne. Według Narajewskiego przedmiot czynu można uznać za 
moralnie dobry, jeśli jest zgodny z rozumną naturą ludzką, a przede wszystkim wolą Boga.

W 1935 r. A. Bukowski napisał artykuł na styku etyki filozoficznej i moralnej zatytułowany Dogmatyczne podstawy chrześcijańskiej solidarności (s. 567-584). Autor, omawiając chrześcijańską ideę solidarności, podkreślił, że pochodzi ona z nadprzyrodzonego objawienia Bożego i buduje naturalną jedność rodzaju ludzkiego. Napisał m.in.: „Skutkiem wspólnego pochodzenia istnieje między wszystkimi ludźmi organiczny związek, wszyscy tworzą jedną całość, jakby ogromne drzewo, którego wszystkie konary i gałązki z jednego pnia i jednego korzenia wyrosły" (s. 569). Zwrócił też uwagę na ogólnoludzką solidarność moralną, czyli na wspólną naturalną odpowiedzialność. Bukowski zaznaczył, że odpowiadamy nie tylko za swoje czyny, ale jesteśmy odpowiedzialności za czyny przodków w ramach dziedziczenia zobowiązań. Autor artykułu w swoich wywodach nawiązał do Pisma Świętego, a szczególnie do grzechu Adama, który rzutował na losy następnych pokoleń. Następnie wskazał, że jak wina Adama obciążyła ludzkość, tak odkupienie Chrystusa przyniosło łaskę każdemu człowiekowi. Według Bukowskiego idea solidarności stała się podstawą budowania królestwa Bożego, a także wspólnoty Kościoła.

Następnie S. Olejnik w artykule Normatywny charakter wartości etycznych (1954 r., s. 162-176) analizował zagadnienie poczucia obowiązku i powinności moralnych w działaniach ludzkich. Autor rozważał znaczenie różnych wartości, które mają kształtować i rozwijać poczucie ludzkiej powinności. Podkreślił też wpływ środowiska społecznego na poczucie obowiązku rozumianego jako pewne wewnętrzne zalecenie czy nakaz. Obowiązek moralny wiązał z imperatywem wartościowania i wewnętrzną aprobatą danego działania ludzkiego. Olejnik napisał, że „normatywność cechuje całą dziedzinę wartości etycznych, wyrażając się zarówno w postaci zalecenia, jak i ścisłego obowiązku. Cała dziedzina tych wartości posiada charakter imperatywno-konsultatywny, o różnym jednak ustopniowaniu imperatywu" (s. 174). 
Ten sam autor w 1955 r. w drugim numerze „Collectanea Theologica” opublikował artykuł zatytułowany Znamiona humanistyczne etyki katolickiej (s. 207-249). Na początku rozróżnił znaczenie pojęć „moralność” i ,etyka”, gdzie pierwsze dotyczy konkretnych ocen zachowania i działania moralnego (badany jest aspekt praktyczny), zaś drugie jest teoretyczną próbą opisania pewnych zjawisk. Dodał też, że etyka katolicka jest pewnym systemem wartościowania opartym na nauce Kościoła. W artykule autor postawił pytanie badawcze: „Czy rzeczywiście etyka katolicka w samych swoich założeniach dehumanizuje życie ludzkie?” (s. 208). Następnie próbował odpowiedzieć na nie w kontekście ówczesnych sporów i dyskusji na ten temat. Autor przypomniał też założenia etyki katolickiej, gdzie na pierwszym miejscu podkreśla się wartość osoby ludzkiej i jej godność. Zaznaczył, że Bóg nie odbiera człowieczeństwa, ale, obdarowując łaską, wynosi człowieka na wyższy poziom natury. Napisał m.in.: „Wzbogacając człowieka swa łaską, Bóg podnosi go ontycznie i aksjologicznie" (s. 211). W dalszej części rozprawy pokazał istotne różnice między założeniami etyki katolickiej i utylitarystycznej. Olejnik odrzucił humanizm antropocentryczny i indywidualistyczny, jednocześnie pokazując wartość humanizmu personalistycznego. $\mathrm{Na}$ koniec podkreślił, że etyka katolicka opiera się na teocentryzmie, gdzie człowiek stworzony przez Boga powinien Mu służyć i w ten sposób może wypełnić swoje powołanie.

W 1955 r. w trzecim zeszycie czasopisma opublikowano kolejny artykuł poruszający tematykę moralną w świetle nauk św. Tomasza z Akwinu zatytułowany Zagadnienie prawa własności $w$ filozofii społecznej św. Tomasza z Akwinu (s. 537-567). Autor artykułu, Piotr Chojnacki, opisał prawo własności w różnych kontekstach społecznych, w tym także w ujęciu moralnym. Podstawą do prowadzenia badań na powyższy temat była koncepcja św. Tomasza z Akwinu nawiązująca do prawa naturalnego. Chojnacki wyjaśnił, że ,według św. Tomasza prawo do własności nie należy do pierwotnego wyposażenia natury ludzkiej; stanowi ono właściwość natury rozumnej ludzkiej” (s. 547). Istotne jest też rozróżnienie w myśli św. Tomasza prawa korzystania z własności w celu zaspokojenia ludzkich potrzeb 
od prawa posiadania własności, które z kolei domaga się roztropnego zarządzania. Autor przytoczył założenie św. Tomasza, który właściwe korzystanie z własności indywidualnej uzależnił od osiągania dobra społecznego. „Dobro ludzkie ogólnie góruje nad dobrem jednostkowym i góruje jako cel naczelny, który powinny mieć na względzie tak jednostki, jak i władza rządząca społeczeństwami” (s. 559).

W numerze z 1968 r. z. 3, J. Pryszmont, w artykule Podstawowe założenia doktryny moralnej Wt. Sołowjewa (s. 69-86), badał myśl filozofa rosyjskiego Wł. Sołowjewa, w tym ideę dobra. Jak napisał autor: „Człowiek bowiem niezależnie od dyscyplin filozoficznych i religijnych wykrywa dobro w swej naturze. Ono to stanowi ogólnoludzki fundament moralności, w oparciu o który powinno się budować system etyczny" (s. 71). Pryszmont zaznaczył, że według Sołowjewa moralność człowieka przejawia się w uczuciach, takich jak: wstyd, współczucie i szacunek do innych ludzi.

W 1969 r. w z. 3 S. Rosik w rozprawie pod tytułem: Prawo moralne, a wolność sumienia (s. 49-64) zajął się stosunkiem prawa moralnego do wolności działającego człowieka. Napisał m.in., że „zejście się powinności prawa i wolności wyboru w człowieku jest stosunkiem napięcia cechującego ludzką egzystencję" (s. 58). Autor poszukiwał w artykule odpowiedzi na pytanie dotyczące zakresu wolności sumienia w postępowaniu etycznym człowieka.

Podobnie w drugim artykule, zatytułowanym Sytuacyjna funkcja sumienia (1970 r. z. 4, s. 33-50), S. Rosik analizował problematykę sumienia ludzkiego w aspekcie jego działania w zależności od różnych sytuacji. Na początku przedstawił różne kierunki sytuacjonizmu etycznego, opierając się na wypowiedziach wybitnych etyków. Napisał, że „cała sfera wartości moralnych i wynikających z nich powinności dochodzi do głosu bezpośrednio w sumieniu, które stanowi subiektywną normę moralności” (s. 38). W podsumowaniu stwierdził, że zgodnie z zaleceniem Konstytucji soborowej Gaudium et spes, w teologii moralnej należy ciągle poszukiwać nowych rozwiązań.

Z kolei w 1971 w z. 1 S. Kowalczyk opublikował artykuł pod tytułem Społeczny charakter człowieka, jako podstawa dialogu chrześcijańsko-marksistowskiego (s. 39-52). Autor poszukiwał w nim 
płaszczyzny dialogu między Kościołem a ideologią marksistowską. Na początku zwrócił uwagę na istotną trudność w podjęciu dialogu ze względu na odmienne pojmowanie człowieka. Następnie przybliżył założenia antropologii materializmu dialektycznego, jednocześnie wskazując przejawy humanizmu marksistowskiego, a także jego aksjologię. W dalszej części artykułu badał elementy zbieżne w antropologii chrześcijańskiej i marksistowskiej. Między innymi doszukał się pewnych podobieństw w odniesieniu do postrzegania społeczeństwa, rodziny czy narodu. Napisał, że „,chrześcijanie i marksiści uważają się zgodnie za lud ziemi i lud historii. (...) Żyjemy wszyscy w społeczeństwie, gdyż potrzebujemy siebie nawzajem” (s. 51).

Należy zauważyć, że w 1972 r. prawie cały zeszyt 2 poświęcono zagadnieniom moralnym. Najpierw B. Häring, w artykule Etyka chrześcijańska $i$ wychowanie $w$ dobie krytyki (s. 5-17), przedstawił słabe i mocne strony aktualnej etyki chrześcijańskiej. Jednocześnie postulował, aby podstawą etyki na ówczesne czasy były nie tyle normy i zasady prawno-moralne, ile naśladowanie Chrystusa rozumianego jako droga, prawda i życie, oraz Jego przesłanie wyrażone w Kazaniu na Górze.

Ostatni czwarty artykuł w tym numerze (1972 r. z. 2) to rozprawa S. Kowalczyka zatytułowana Marksistowska a chrześcijańska koncepcja wolności (s. 53-70). Autor kontynuował w nim studia nad związkami marksizmu i chrześcijaństwa podjętymi rok wcześniej. Napisał, że celem jego badań było ,zarysowe przedstawienie koncepcji wolności dwu współczesnych nurtów ideologicznych: marksizmu i chrześcijaństwa" (s. 53). Kowalczyk poszukiwał zatem podobieństw i różnic między ujęciem marksistowskim i chrześcijańskim odnośnie do idei wolności. Na końcu artykułu autor podkreślił odrębność w pojmowaniu człowieka i jego wolności w omawianych systemach. Stwierdził m.in., że ,różnice systemowo-ideologiczne, dzielące chrześcijaństwo i marksizm, są nie do zakwestionowania i stanowią wciąż nieprzekraczalny hiatus" (s. 69).

Następnie M. Gogacz w artykule Odpowiedzialność osobowa $i$ wspólnotowa (1972 r. z. 4, s. 39-51) zajął się kwestią odpowiedzialności indywidualnej i zbiorowej i jej powiązań ze sprawiedliwością 
i miłością. Autor napisał, że odpowiedzialność to ,wzięcie na siebie skutków własnego lub czyjegoś działania" (s. 40). W dalszej części artykułu omówił zarówno przejawy odpowiedzialności osobowej, jak i wspólnotowej, które powinny prowadzić do prawidłowego i pełnego korzystania z faktu międzyosobowych relacji.

W 1973 r. w z. 1 opublikowano dwa artykuły, w których autorzy badali tożsamość etyki chrześcijańskiej. W pierwszym dość krótkim artykule Swoistość etyki chrześcijańskiej K. Böckle (s. 5-14) opisał fundamentalne założenia moralności chrześcijańskiej. Wskazał też jasne kryteria biblijne, które od czasów apostolskich pozwalały wiernym podejmować właściwe decyzje moralne. W dalszej części artykułu zauważył, że obecnie kwestie prawne zbytnio przysłoniły orędzie Chrystusa. Napisał, że „w tym względzie musiałaby się dokonać istotna zmiana w teologii moralnej, w zakresie jej funkcji przepowiadania" (s. 13). Jednak autor nie doprecyzował, na czym ta zmiana w teologii moralnej miałaby polegać.

Z kolei w drugim artykule tego zeszytu G. Ziegler postawił ważne pytanie już w tytule swego tekstu: Czy istnieje etyka specyficznie chrześcijańska? (s. 15-28). Autor rozprawy nawiązał do dysputy posoborowej związanej z krytyką zbytniego akcentowania prawa w Kościele, a także z zagadnieniem sposobu ustalania absolutnych i niezmiennych norm moralnych w chrześcijaństwie. W konkluzji stwierdził, że ,etyka chrześcijańska nie jest etyką norm, lecz etyką nad normami. Łaska zakłada moralność naturalną i sposobami nadnaturalnymi doprowadza ja do pełni” (s. 27).

W 1973 r. w z. 3 ukazał się artykuł J. Piegsy Czy prawo moralne sprzeciwia się wolności? (s. 67-74). Na początku autor postawił fundamentalne pytanie: „Czy można w ogóle mówić o wolności tam, gdzie należy zachowywać przykazania?” (s. 67). Piegsa, omawiając istotę chrześcijańskiej wolności, zwrócił uwagę, że już sama wiara wyzwala chrześcijanina od grzechu i śmierci oraz od poddaństwa prawu. W podsumowaniu autor napisał, że „odpowiedź, którą znajdujemy w Ewangelii Chrystusa jest tą prawdą, która jedynie i rzeczywiście jest w stanie nas wyzwolić" (s. 73). 
Także K. Hörmann, w artykule Co to jest moralność chrześcijańska? (1977 r. z. 2, s. 61-68), włączył się w nurt dyskusji na temat posoborowej tożsamości teologii moralnej. Hörmann sformułował pytania, które miałyby pomóc w określeniu roli i zadań etyki chrześcijańskiej. Do pytania postawionego w tytule dodaje kolejne, a mianowicie: „Co winniśmy czynić?” Jednocześnie podkreślił, że nie znajdziemy w Piśmie Świętym szczegółowej odpowiedzi na tak postawione pytanie. Napisał, że ,chrześcijanin wciąż na nowo staje przed koniecznością osobistego badania i oceniania, w czym hic et nunc wyraża się w stosunku do niego wola Boża" (s. 61). Dodał też, że podobnie w tradycji Kościoła trudno znaleźć konkretne i aktualne wskazania moralne. Hörmann w podsumowaniu zaznaczył, że „miłość zarówno Boga jak i bliźniego jest znamieniem prawdziwego ucznia Chrystusowego" (s. 66).

Następnie T. Ślipko, w artykule Rozwój etycznej myśli Karola kard. Wojtyty (1980 r. z. 2, s. 49-74), badał dorobek naukowy nowego papieża w zakresie etyki i moralności. Autor na początku pracy napisał, że „o kard. Wojtyle mówi się zazwyczaj, że jest on przede wszystkim teologiem-moralistą, nie zaś filozofem-etykiem" (s. 50). Ślipko w rozprawie analizował publikacje Wojtyły zarówno z zakresu filozofii, jak i etyki, oraz oceniał ich wartość naukową. Na koniec przedstawił koncepcję personalistyczną kard. Wojtyły na podstawie jego artykułów naukowych.

Kolejną pracą nawiązującą do myśli filozoficzno-moralnej św. Tomasza z Akwinu jest rozprawa J. Salija Mądrość $i$ głupota w refleksji św. Tomasza z Akwinu (1982 r. z. 4, s. 21-29). Autor napisał we wstępie, powołując się na św. Tomasza: „Nasza przyszłość nie jest zdeterminowana, lecz kształtują ją nasze wolne wybory. Dlaczego jednak - pyta św. Tomasz - liczne przepowiednie, dotyczące spraw, które podlegają wolnemu wyborowi się sprawdzają? Bo większość z nas postępuje głupio i zamiast podporządkować sobie różne siły, które wywierają na nas swój nacisk, sami dajemy się im kierować" (s. 21). Autor zwrócił uwagę, że św. Tomasz radził, by nie ulegać skłonnościom emocjonalnym, wyobrażeniom albo uczuciom pożądania zmysłowego, takim jak: gniew, strach czy niepokój, gdyż 
prowadzą one do zachowań niemoralnych. Uważał też, że mądry człowiek ma panować nad swoimi pragnieniami. Salij zauważył, że mądrość bądź głupota przejawia się nie tylko w myśleniu, ale przede wszystkim w działaniu. Podał sześć cech mędrca na podstawie pism św. Tomasza z Akwinu. Pierwszą z nich jest ogarnianie całej rzeczywistości, czyli określenie tego, co najbardziej powszechne. Drugą - umiejętność pokonania poważnych trudności. Trud zdobywania mądrości, który prowadzi do pewności wiedzy, to trzeci składnik. Z kolei czwarty element to rozumienie równoważne ze znajomością przyczyn. Piąty komponent to szukanie mądrości dla niej samej. Oznaką szóstej cechy jest porządek, zarówno w myśleniu, jak i postępowaniu. Na koniec stwierdził, że głupota jest czymś innym aniżeli brak inteligencji czy umysłowy niedorozwój; głupota jest zamknięciem człowieka na ostateczną przyczynę rzeczywistości.

W 1996 r. w z. 4 P. Bortkiewicz w artykule Ważność świadectwa prawdzie $w$ dobie ponowoczesności (s. 105-113) poruszył kwestię rozumienia prawdy w dobie obecnej. Punktem wyjścia jego rozważań był tekst z Nowego Testamentu, w którym jest mowa o dialogu Piłata z Jezusem na temat prawdy. Autor analizował pojęcie prawdy zarówno w aspekcie subiektywnym, jak i obiektywnym odnosząc swoje uwagi do współczesności.

W następnym zeszycie „Collectanea Theologica” z 2009 r. (z. 3) R. Czekalski w artykule zatytułowanym Recepcja pojęcia ,autonomia" w katolickiej teologii moralnej (s. 81-94), badał problem niezależności teologii moralnej w ujęciu A. Auera, twórcy etyki autonomicznej. Autor w podsumowaniu napisał, że „cały spór między etyką autonomiczną sprowadza się do koncepcji człowieka" (s. 94).

Z kolei A. F. Dziuba w artykule Etos chrześcijański powołaniem do wolności (2011 r. z. 3, s. 63-77), zajął się problemem wolności w świetle moralności chrześcijańskiej. Autor w artykule omówił związki wolności z moralnością. Napisał, że „wolność nie jest jedynie wartością dla osoby, ale jej istotną właściwością i nieusuwalnym atrybutem, świadczący o jej podmiotowości” (s. 63). Dziuba przypomniał też słowa św. Pawła, który nauczał, że do wolności powołał na Chrystus. 
W późniejszym artykule zatytułowanym Problematyka wolności sumienia w świetle współczesnych wyzwań (2016 r. z. 1, s. 85-106) M. Machinek na początku przedstawił pewne trudności definicyjne odnośnie do sumienia. Następnie przedstawił katolicko-moralną wykładnię na temat sumienia. Według Machinka istotnym współczesnym wyzwaniem w odniesieniu do wolności sumienia jest nie tylko subiektywizacja czy relatywizacja moralności, ale nowe uwarunkowania społeczne i polityczne podważające wszelkie wartości.

\section{Tematyka psychologiczno-moralna}

Teologia moralna coraz częściej korzysta z dorobku dyscyplin naukowych, które pozwalają lepiej zrozumieć człowieka oraz jego zachowania w społeczeństwie. Do takich nauk należy psychologia, która bada różne uwarunkowania psychiczne człowieka. Należy podkreślić, że dane z zakresu psychologii, które przynoszą wiele cennych informacji o człowieku, mogą być przydatne w refleksji teologiczno-moralnej.

I tak S. Kuczkowski w artykule Struktura i dynamika poczucia winy (1974 r. z. 3, s. 41-52) opisał symptomy poczucia winy u pacjentów w ujęciu psychologiczno-moralnym. Autor zaliczył poczucie winy do pewnych zaburzeń i nerwic ludzkich. Następnie rozważał objawy poczucia winy zarówno od strony emocjonalnej, jak i moralnej. Napisał, że „obecność poczucia winy jest sygnałem, że równowaga w świadomości moralnej uległa zachwianiu" (s. 49).

W z. 4 z 1980 r. T. Sikorski, w artykule $O$ chrześcijańska postawe wobec problemu samobójstwa (s. 43-59), zwrócił uwagę na narastający w społeczeństwie problem samobójstw jako wyzwanie dla teologów i filozofów chrześcijańskich. Autor na początku zauważył, że podręcznikowy wykład z teologii moralnej na temat samobójstwa jest przestarzały. Postulował, aby na nowo odczytać sens piątego przykazania w duchu badań egzegetycznych, a także brać pod uwagę czynniki psychologiczne, np. poczucie krańcowego opuszczenia. Sikorski napisał, że „samobójstwo jest paradoksalnym i dramatycznym finałem krańcowego osamotnienia, ludzkiej bezradności i utraty 
nadziei w impasie życiowym, zastanowienia etyka powinny wskazać normę i praktykę doskonałego współistnienia jako podstawowe wezwanie moralne" (s. 58).

Następnie S. Kisiel w artykule Niektóre psychologiczne aspekty kształtowania sumienia (1985 r. z. 4, s. 61-70) już na początku rozprawy uzasadnił podjęcie powyższego tematu w słowach: „Wychowanie człowieka odbywa się przez kształtowanie jego sumienia” (s. 61). Następnie analizował różne koncepcje, zarówno psychologiczne, jak i pedagogiczne, w odniesieniu do wychowania i formowania sumienia usposobionego prospołecznie.

Podobnie w 1987 r. w z. 2 M. Wolicki w artykule Sumienie i superego a poczucie winy (s. 63-74) zajął się różnymi koncepcjami sumienia. Na początku artykułu analizował trzy rodzaje sumienia: wrodzonego, nabytego i integralnego. W dalszej części publikacji zastanawiał się nad relacją do sumienia Freudowej koncepcji superego. Napisał, że ,warto przybliżyć sobie niektóre poglądy Freuda i jego szkoły dotyczące superego, by na tym tle lepiej zobaczyć różnicę między superego a sumieniem wrodzonym" (s. 66). Na koniec omówił przykłady poczucia winy jako określony przejaw działającego sumienia.

Także w 1989 r. (w z. 3) M. Wolicki zamieścił artykuł Zaburzenia nerwicowe a sumienie (s. 51-57) w świetle dwóch dziedzin naukowych: psychologii i teologii moralnej. Autor pokazał w nim zależność między niedomaganiami sumienia, w tym zaburzeniami nerwicowymi, a chorobami psychicznymi. Napisał m.in.: „Na związek nerwicy z sumieniem zwraca uwagę wielu autorów, którzy (...) określają neurozę jako chorobę złego sumienia" (s. 53).

W z. 2 z 1990 r. E. Kowalski, w artykule Konflikt sumienia (s. 5-13), zajął się kwestią sumienia w świetle psychologii społecznej. Napisał, że proces rozwoju sumienia „odbywa się pod wpływem zastanych genetycznie uwarunkowanych skłonności, obciążeń psychofizycznych, a także pod wpływem oddziaływania zewnętrznych środowisk wychowawczych" (s. 6). Autor zauważył, że człowiek uświadamia sobie obiektywne wartości moralne, które pragnie urzeczywistnić, 
czyli dopasować do swego życia. Niemożność osiągnięcia pewnej doskonałości moralnej prowadzi do konfliktu sumienia.

W tym samym numerze znajdujemy drugą publikację tego samego autora, poświęconą problematyce sumienia (E. Kowalski, Funkcjonowanie subiektywnej normy moralności, s. 35-43). Autor w artykule przedstawił różne koncepcje wybranych filozofów, psychologów bądź socjologów na temat sumienia. Napisał, że „,według E. Durkheima sumienie jest głosem społeczeństwa odzywającym się w człowieku" (s. 37). Kowalski podkreślił, że sąd sumienia jest wypadkową zarówno porządku obiektywnego, jak i subiektywnego w konkretnych wyborach i decyzjach moralnych.

\section{Tematyka pastoralno-moralna}

W kolejnej części tematycznej podkreślono potrzebę zaangażowania katolików świeckich w dzieło misji i ewangelizacji. Autorzy w swych artykułach zwracali uwagę na ważność właściwej formacji i wychowania moralnego.

W 1969 r., w z. 1, M. Bigaj i W. Domański przedstawili badania dotyczące postaw moralnych ludzi młodych w artykule Postawy etyczne młodzieży licealnej (s. 57-72). Na początku wyjaśnili znaczenie terminów „postawy” i „motywy”, których używali w kwestionariuszu w ramach przeprowadzonego testu. Następnie omówili metodę i pytania badawcze skierowane do młodych, aby na końcu podać wyniki prac badawczych.

W kolejnym numerze (1972 r. z. 3) B. Brzuszek w artykule zatytułowanym Zobowiązanie wiernych świeckich do apostolstwa (s. 65-74) opisał kwestię odpowiedzi chrześcijan na powołanie Boga do uczestnictwa w posłannictwie apostolskim, wynikającym z przyjęcia sakramentów chrztu i bierzmowania. Autor rozprawy już na początku postawił pytania badawcze: „W jakim zakresie, kiedy i w jakim stopniu wierni są zobowiązani apostołować?” (s. 65). Następnie wyjaśnił, że świeccy na mocy sakramentów chrztu i bierzmowania mają udział w trzech funkcjach Chrystusa: kapłańskiej, profetycznej 
i królewskiej. Na końcu Brzuszek podkreślił, że przynależność do Chrystusa i Kościoła zobowiązuje wiernych do działań apostolskich i misyjnych.

Następnie E. Ożóg w rozprawie Powołanie religijne i jego kryteria (1975 r. z. 1, s. 19-32) opisał kwestię powołania w perspektywie psychologii i zasad moralnych. Autor artykułu podkreślił, że sposób realizacji powołania ma istotny wpływ na proces rozwoju osobowości człowieka. Dodał też, że w seminariach diecezjalnych czy zakonnych powinno się odchodzić od wychowania biernego, gdzie kleryk jedynie słucha i wykonuje polecenia, ale trzeba tworzyć takie warunki, które pozwalałyby na świadome i dobrowolne podejmowanie określonych działań przez alumnów. Jak stwierdził Ożóg, „doskonałość człowieka ma charakter moralny i dlatego (...) musi poznać jej wartość, a następnie chcieć w sposób skuteczny realizować je w swoim życiu” (s. 19).

$\mathrm{Z}$ kolei R. Murawski w artykule Rozwój $i$ wychowanie moralne dzieci i młodzieży (1980 r. z. 1, s. 35-52) zwrócił uwagę na konieczność wychowania moralnego młodzieży na katechezie. Autor napisał, że „katecheza ma objąć nie tylko to, w co trzeba wierzyć, ale również i to, co należy czynić" (s. 35). W dalszej części artykułu Murawski omówił niewłaściwe systemy wychowania moralnego, oparte na relatywizmie moralnym czy indoktrynacji. Na koniec publikacji autor przybliżył teorię rozwoju moralnego w ujęciu L. Kohlberga.

W 1985 r. w z. 2 S. Kisiel, w artykule Zwiazek rozwoju moralnego z rozwojem religijnym człowieka (s. 29-41), podjął zagadnienie wpływu religii na postawy moralne. Na samym początku autor napisał, że „treść i jakość postawy moralnej kształtuje się w oparciu o wartości” (s. 31). W dalszej części artykułu Kisiel opisał badanie związków religii z moralnością, opierając się na znanym teście L. Kohlberga pokazującym trzy poziomy rozwoju moralnego. Autor w podsumowaniu potwierdził, że zasady religijne mają istotny wpływ na wybory i zachowania moralne i sytuują się na poziomie drugim.

Ten sam autor (S. Kisiel) w artykule Niektóre aspekty ksztattowania u młodzieży dojrzałego sumienia (1986 r. z. 2, s. 55-64) zajął się kwestią dojrzałości i świadomości moralnej młodzieży. Najpierw wyjaśnił cechy dojrzałego sumienia, a następnie opisał sposoby 
formowania takiego sumienia. Napisał m.in., że ,im bardziej osoba jest dojrzała moralnie, tym bardziej jest przekonana, że jej własne dobro jest nierozdzielnie związane z dobrem innych osób" (s. 56).

W kolejnym zeszycie A. F. Dziuba, w artykule Dynamika człowieka wiary (1991 r. z. 2, s. 73-83), zwrócił uwagę na konieczność pełnego zaangażowania się wiernych w realizacji chrześcijańskiego powołania. Według Dziuby człowiek powinien odznaczać się dynamizmem nie tylko w czynnościach i pracach codziennego życia, ale również w relacjach do drugiego człowieka, a przede wszystkim do Boga.

W 2000 r. (z. 3) W. Chrostowski w artykule Zasady etyczne $w$ opiece nad umierającym człowiekiem w nauczaniu Kościoła katolickiego (s. 89-108) przypomniał wypowiedzi i naukę Kościoła w kwestii cierpienia i umierania. Zaznaczył też, że „dokonywanie ocen i normowanie prawidłowych moralnie działań odnośnie do kresu życia ludzkiego opiera się zatem na kryteriach podkreślających świętość życia i jego nienaruszalność" (s. 92). Autor zwrócił uwagę na potrzebę uaktualnienia pewnych propozycji i rozwiązań w nauczaniu Kościoła odnośnie do śmierci i opieki nad umierającym. Podkreślił, że ,podstawą religijnej opieki nad umierającym powinna być ewangelizacja śmierci jako obowiązek duszpasterski całej wspólnoty eklezjalnej" (s. 108).

W następnym numerze A. Bohdanowicz, w artykule Moralne aspekty postugi w konfesjonale u progu XXI wieku (2007 r. z. 1, s. 107-121), rozważał przyczyny obecnego kryzysu praktyki sakramentu pokuty. Już na samym początku jako jedną z istotnych przyczyn wskazał ,osłabienie zmysłu moralnego i religijnego, zanik poczucia grzechu" (s. 107). Autor poszukiwał nowych sposobów dotarcia do wiernych, m.in. zaproponował nietypowe formy spowiedzi, takie jak internet czy ,jeżdżące konfesjonały”.

\section{Tematyka katolickiej nauki społecznej}

Katolicka nauka społeczna, wyrosła na bazie papieskich encyklik, adhortacji czy innych opracowań, analizuje przede wszystkim 
sprawy społeczno-polityczne czy gospodarcze. Należy podkreślić, że katolicka nauka społeczna rozważa działalność człowieka w wymiarze społecznym w świetle zasad: pomocniczości, dobra wspólnego, solidarności i powszechnego przeznaczenia dóbr. Do powyższych zasad katolickiej nauki społecznej w swoich artykułach badawczych nawiązują przede wszystkim następujący autorzy: W. Piwowarski, J. Krucina, H. Skorowski, A. F. Dziuba i K. Kietliński.

W ostatnim w 1957 r. z. 3-4, S. Olejnik opublikował artykuł pod tytułem: Etos i etyka pracy zawodowej (s. 540-561). Autor na początku wyjaśnił rozumienie pracy zawodowej, która zawsze zawiera pewną treść aksjologiczną i normatywną. Można zatem mówić w odniesieniu do pracy ludzkiej o pewnej moralności zawodowej. Jednocześnie Olejnik zauważył, że „nie da się wyraźnie oddzielić sfery zawodu od sfery człowieczeństwa”, czyli etyki zawodowej od etyki ogólnej (s. 547).

W 1963 r. (z. 1-4) B. Inlender w artykule Społeczne uwarunkowanie moralności jako problem w etyce normatywnej (s. 80-90) analizował kwestię moralności w życiu społecznym. Autor artykułu zajął się oceną tezy, która pojawiła się wraz z rozwojem nauk socjologicznych, a przede wszystkim socjologii moralności, że moralność jest społecznie uwarunkowana. Na początku zwrócił uwagę, że „uzależnienie moralności od czynników społecznych świadczy o relatywnym charakterze moralności w ogóle" (s. 83). Wyjaśnił też znaczenie pojęć, takich jak: „moralność”, „uwarunkowania” oraz „wymiar społeczny”. Inlender po zweryfikowaniu powyższej hipotezy odrzucił relatywistyczny model etyki propagowany przez przedstawicieli socjologii moralności. Autor w podsumowaniu opowiedział się za istnieniem konkretnych norm absolutnych i niezmiennych, niezależnych od uwarunkowań społecznych.

Następnie w 1971 r. w z. 4 W. Piwowarski, w artykule Zasada pomocniczości $w \dot{z} y c i u$ Kościoła, badał wpływ powyższej reguły na funkcjonowanie społeczeństwa i Kościoła (s. 5-23). Najpierw przedstawił rys historyczny rozwoju zasady pomocniczości począwszy od encykliki Piusa XI Quadragesimo anno (1931 r.) aż do czasów obecnych. Autor podkreślił, że zasada pomocniczości „stanowi trzon 
wszystkich nowszych dokumentów społecznych Kościoła” (s. 5). W artykule precyzyjnie wyjaśnił istotę i możliwości zastosowania tej zasady. Na koniec postulował potrzebę wdrożenia zasady pomocniczości w Kościele, bo przyczyniłaby się ona do decentralizacji i odbiurokratyzowania jego instytucji.

W kolejnym zeszycie T. Ślipko w artykule zatytułowanym Rozwój podstawowych zagadnień społecznej nauki papieży (1972 r. z. 1, s. 5-20) zajął się analizą społeczno-gospodarczych kwestii w świetle nauki Kościoła. Autor rozpoczął rozprawę od omówienia złożonej problematyki społecznej, przede wszystkim kwestii robotniczej w encyklice Rerum novarum papieża Leona XIII. Przypomniał, że papież „potępia nadużycia liberalnego kapitalizmu, broni prawa człowieka do własności prywatnej, podkreśla osobową wartość pracy robotnika, wysuwa wreszcie postulat sprawiedliwej płacy" (s. 9). Następnie omówił kolejne encykliki (Quadragesimo anno i Mater et magistra) poruszające podobne zagadnienia społeczno-ekonomiczne. Ślipko przedstawił zatem doktrynę Kościoła katolickiego, opartą na idei sprawiedliwości, będącą podstawą do oceny ówczesnych zjawisk społeczno-gospodarczych.

Artykuł W. Jachera, zatytułowany Moralność jako czynnik integracji społecznej w ujęciu Emila Durkheima (1972 r. z. 1, s. 45-61), jest kolejną rozprawą w tym numerze, w której pojawiają się aspekty społeczno-moralne. Jacher badał powyższe zagadnienie przede wszystkim z perspektywy socjologicznej i filozoficznej, a sprawom moralnym poświęcił jeden paragraf. Zaznaczył, że społeczeństwo łączą normy, nakazy i zakazy czy też ideały zbiorowe, a więc pewne wartości. Zatem „w takim ujęciu moralność spełnia ważną rolę jako czynnik spójności społecznej” (s. 51). Według autora artykułu Emil Durkheim, zajmujący się socjologią moralności, twierdził, że społeczeństwo nie mogłoby istnieć bez wartości moralnych. Dodał też, że w koncepcji Durkheima moralność powinna być podporządkowana socjologii, gdyż ,celem i twórcą moralności jest społeczeństwo" (s. 57). Jacher w zakończeniu artykułu podkreślił, że wizja moralności społecznej Durkheima opierała się na trzech elementach, takich jak: duch dyscypliny, powiązanie z grupą społeczną 
i autonomia woli. Te trzy czynniki miały zapewnić ład i porządek moralny w społeczeństwie.

Następnie J. Krucina w 1972 r. (w z. 2) opublikował artykuł pod tytułem: Spór między katolicką nauka społeczna a teologia polityczna autorstwa (s. 39-51). Autor w rozprawie najpierw wyjaśnił podstawowe zasady społecznej nauki Kościoła w dokumentach papieskich. Następnie pokazał źródła konfliktów teologii politycznej z katolicką nauką społeczną wynikających głównie z odmiennych założeń i celów. Krucina zwrócił uwagę, że katolicka nauka społeczna, według zwolenników teologii politycznej, jest zbyt teoretyczna i całkiem nieprzydatna w rzeczywistości społecznej. W podsumowaniu napisał, że ,teologia polityczna może odegrać w stosunku do społecznej nauki Kościoła rolę komplementarną, zastąpić jej jednak nie zdoła" (s. 50).

W następnym numerze W. Piwowarski w artykule Pokój jako podstawowa wartość w społecznym nauczaniu Kościoła (1986 r. z. 3, s. 5-17) najpierw przypomniał wypowiedzi i przemówienia papieży, a także dokumenty II Soboru Watykańskiego na temat pokoju. W dalszej części artykułu badał powyższy problem w ujęciu filozoficznym i socjologicznym. Napisał, że ,tradycyjne spojrzenie na pokój to dawne legitymizacje pokoju, w ramach których pokój rozumiano jako stan bez wojny i rewolucji, czyli brak jawnego stosowania przemocy" (s. 6). Zwracał uwagę, że Kościół w dokumentach soborowych zakwestionował tradycyjny model pokoju, w którym wojna mogła być uznana za środek konieczny do osiągnięcia pokoju, a zaproponował nowe jego rozumienie. Piwowarski wyjaśnił, że Kościół proponuje personalistyczne ujęcie pokoju światowego, w którym najważniejsze są godność i prawa człowieka.

Z kolei H. Skorowski w artykule Prawa człowieka $w$ stużbie wolności (1988 r. z. 4, s. 27-38) zajął się kwestią wolności w perspektywie praw człowieka. Autor już na początku zaznaczył, że jego celem jest ukazanie związków praw człowieka z ideą wolności. Przypomniał także encyklikę Jana XXIII Pacem in terris, w której rozpatrywano zagadnienie wolności w czterech płaszczyznach: kulturowej, małżeńsko-rodzinnej, społeczno-gospodarczej i politycznej. W dalszej 
części artykułu Skorowski badał różne dokumenty międzynarodowe podejmujące problem praw człowieka w odniesieniu do wolności.

W 1989 r. w z. 1 A. Marcol w artykule Sprawiedliwość ekonomiczna dla wszystkich (s. 5-17) ocenił treść listu biskupów amerykańskich na temat sprawiedliwości ekonomicznej, opublikowanego 13 listopada 1986 r. Autor prześledził pięć rozdziałów powyższego dokumentu z perspektywy katolickiej nauki społecznej. Marcol napisał, że sprawiedliwość „oznacza nie tylko udział wszystkich obywateli w życiu polityczno-społecznym, lecz także ich partycypację w dobrach ekonomicznych" (s. 5). W dalszej części artykułu przybliżył postulaty społeczno-gospodarcze biskupów amerykańskich odnośnie do poprawy warunków życia obywateli, mających charakter otwarty i dialogiczny. W podsumowaniu autor stwierdził, że w realizacji sprawiedliwości ważną rolę odgrywa partycypacja na różnych szczeblach życia społecznego.

W 1990 r. (w z. 4) I. Mroczkowski w artykule Teologiczny wymiar praw człowieka (s. 63-74) zwrócił uwagę na nowe możliwości interpretacji praw człowieka po II Soborze Watykańskim. Autor wskazał też złożoność problematyki praw człowieka w perspektywie historii Kościoła. Napisał, że ,jakakolwiek dyskusja na temat promocji praw człowieka i ich wymiaru moralnego nie może przeoczyć faktu, że człowiek, jako stworzeniem Boże, stoi w relacji do Boga" (s. 69). Podkreślił, że same prawa człowieka nie rozwiążą problemów ludzkości, ale potrzebne jest łączenie ich z solidarnością, która jest cnotą chrześcijańską. W uzasadnieniu Mroczkowski napisał, że „solidarność rozumiana jako obowiązek moralny nie tylko uzupełnia prawa człowieka, ale także stanowi ich zabezpieczenie" (s. 73).

Następnie w krótkim artykule, zatytułowanym Godność osoby jako podstawa chrześcijańskiej koncepcji praw człowieka (1992 r. z. 2, s. 71-79), H. Skorowski rozważał kwestię godności osoby w świetle praw człowieka.

Także w tym roku (1992 r. z. 3, s. 43-56) J. Zabielski, w artykule Uzasadnienie norm moralnych w nauce społecznej Jana Pawła II, podjął kwestię norm moralnych, wskazując ich źródło, treść i moc zobowiązującą w myśli papieża Jana Pawła II. 
W kolejnym zeszycie w 2000 r. B. Mierzwiński w artykule Nowa teologia pracy jako zadanie Kościoła, (z. 3, s. 71-88) poszukiwał nowoczesnej wizji katolickiej teologii pracy. Napisał, że „spojrzenie na ludzką pracę ze strony Kościoła katolickiego obejmuje coraz to nowe horyzonty, uwzględniając zmieniającą się rzeczywistość" (s. 72). Autor omówił koncepcje wybranych teologów o pracy w odniesieniu do współczesności. Zwrócił uwagę na potrzebę humanizacji pracy, a więc przesunięcia akcentu na człowieka, który jest podmiotem pracy.

W 2000 r. w z. 4 J. Zabielski w artykule Osoba jest prawem: personalistyczno-normatywny charakter praw człowieka (s. 55-66) badał moc wiążącą tych praw w ujęciu moralnym. Punktem wyjścia rozważań Zabielskiego były zapożyczone słowa od Antoniego Rosminiego, że „osoba jest prawem”. Autor artykułu napisał, że ,podstawą owej definicji jest istota i charakter działania bytu osobowego" (s. 56).

Z kolei w 2002 r. J. Bramorski opublikował dwa artykuły o tematyce społeczno-moralnej. Najpierw w z. 3 tekst: Postmodernizm jako wyzwanie dla moralności chrześcijańskiej (s. 73-90), w którym już na początku wyjaśnił znaczenie pojęcia „postmodernizm”. Napisał, że ,podstawową ideą postmodernizmu jest odrzucenie tradycyjnego pojęcia prawdy obiektywnej”, a także zanegowanie norm moralnych (s. 74). Autor zwrócił uwagę, że w świecie postmodernistycznym nowymi zasadami moralnymi stały się pluralizm i tolerancja.

Następnie ten sam autor w artykule Społeczny wymiar grzechu jako zniewolenia (2002 r. z. 4, s. 77-94) analizował niszczącą siłę zła społecznego w wymiarze religijnym. Zauważył, że „każdy grzech jest grzechem społecznym, albowiem naruszając więź z Bogiem i pomniejszając człowieka, przyczynia się do tego, że ten, kto grzeszy, nie może w pełni urzeczywistnić swego powołania we wspólnocie" (s. 83). Autor opisał różne formy zniewolenia spowodowane grzechem społecznym. Bramorski podkreślił, że także grzechy osobiste rzutują na powstawanie grzesznych struktur społecznych.

W 2003 r. w z. 3, M. Machinek, w artykule Matżéstwo - inaczej?: tło i skutki społeczne prawnej legalizacji związków homoseksualnych (s. 105-118) zajął się aktualnym problemem związków 
homoseksualnych, które coraz częściej domagają się od społeczeństwa zrównania ich w prawach z małżeństwami. Autor na początku przypomniał, że w historii ludzkości ocena takich zachowań seksualnych była negatywna. Zaznaczył, że także przekaz biblijny był zawsze krytyczny wobec orientacji homoseksualnych. Na koniec przedstawił niezmienne stanowisko Kościoła, który nie uznaje związków homoseksualnych za małżeństwa, ale domaga się od wiernych uszanowania godności osób je tworzących.

W następnej rozprawie, zatytułowanej Społeczno-etyczny porzadek pracy ludzkiej w nauczaniu Ojca Świętego Jana Pawła II, A. F. Dziuba (2006 r. z. 1, s. 79-92) omówił problem pracy w świetle encykliki Jana Pawła II Laborem exercens. Napisał, że ,praca jest powinnością moralną, ponieważ jest koniecznym środkiem zaspokojenia podstawowych, osobowych i społecznych potrzeb człowieka" (s. 88). Autor podkreślił, że w kwestii pracy należy brać pod uwagę nie tylko czynniki ekonomiczne, ale przede wszystkim antropologiczne i aksjologiczne.

W 2007 r. w z. 2 K. Kietliński w artykule Etyczne wybory w konsumpcji (s. 69-82) omówił dylematy nadmiernej konsumpcji w perspektywie moralnej. Na początku napisał, że ,zjawisko konsumizmu jest szczególnym przejawem współczesnej kultury" (s. 70). W dalszym fragmencie artykułu przedstawił współczesne przejawy i zagrożenia konsumizmu, a następnie zajął się oceną moralną zjawiska nieumiarkowanej konsumpcji.

Dwa lata później ten sam autor w artykule Aspekty etyczne prawa własności intelektualnej (2009 r. z. 1, s. 103-117) zajął się opracowaniem problemu własności intelektualnej w ujęciu prawno-moralnym. Na początku omówił historię prawa własności intelektualnej, a następnie przedstawił wypowiedzi Kościoła katolickiego na jej temat. Napisał, że „Kościół jest świadomy przejścia we współczesnym świecie od własności materialnych, tradycyjnych, ziemskich zasobów naturalnych i środków produkcji do nowatorskich typów własności niematerialnej opartej na wiedzy" (s. 110). Kietliński w rozprawie postulował konieczność szukania równowagi między ochroną własności 
intelektualnej i potrzebami społeczeństwa, które należy rozwiązywać z uwzględnieniem zasad moralnych.

W 2010 r. w z. 1 A. Bohdanowicz w artykule Cnota umiarkowania w polityce (s. 123-134) zaproponował, aby w polityce zastosować cnotę umiarkowania. Napisał, że ,cnota umiaru pozwala człowiekowi osiągać harmonię cielesną i duchową" (s. 123). Autor w swoich rozważaniach nawiązał do czterech cnót kardynalnych, do których filozofowie klasyczni zaliczali umiar. Bohdanowicz rozważał też różne zastosowania cnoty umiaru w działalności politycznej i sprawowaniu władzy.

\section{Tematyka biomedyczno-moralna}

W kolejnym obszarze badawczym w perspektywie interdyscyplinarnej skoncentrowano się na problematyce moralno-medycznej. Należy zauważyć, że tematyka ta należy do często podnoszonych, a jednocześnie do najbardziej dyskutowanych problemów współczesnego społeczeństwa. W poszczególnych rozprawach autorzy poszukiwali odpowiedzi na aktualne wyzwania dotyczące przekazywania życia i regulacji poczęć.

W pierwszym numerze „Collectanea Theologica” w 1955 r. S. Olejnik podjął nowatorski temat z zakresu moralności i medycyny. W artykule Eksperyment lekarski na człowieku w świetle oceny etycznej (s. 159-192) zajął się oceną moralną dopuszczalności przeprowadzania testów medycznych na człowieku. $Z$ jednej strony podkreślił znaczenie eksperymentów w rozwoju badań i nauk medycznych, a $z$ drugiej wskazał na wielorakie trudności w przeprowadzaniu testów na ludziach. Autor stwierdził, że „każdy lekarz, wykonując czynności swego zawodu, eksperymentuje i eksperymentować musi. Tego domaga się jego sztuka przy widocznych i nieuniknionych brakach wiedzy lekarskiej” (s. 164). Olejnik, uznając godziwość eksperymentów lekarskich, jednocześnie podkreślił konieczność brania pod uwagę pewnych okoliczności w przeprowadzaniu eksperymentu, które mogą w sposób istotny naruszać uprawnienia osoby ludzkiej. Zaznaczył, że warunkami ograniczającymi eksperymentowanie na 
ludziach są m.in.: zbyt duże ryzyko, niezachowanie zasady primum non nocere, brak odpowiednich kompetencji czy nieuzyskanie zgody pacjenta. Człowiek nie może być traktowany przedmiotowo, jako środek do osiągnięcia postępu medycyny. Według Olejnika „eksperymentowanie na człowieku dla celów badawczych, czyli z zamiarem potwierdzenia pewnych hipotez, czynione bez swobodnie wyrażonej zgody, jest czymś niegodziwym i w zasadzie ciężko grzesznym" (s. 174).

$\mathrm{Z}$ kolei T. Ślipko, w rozprawie Czy pigutki antyowulacyjne moga stanowić środek etycznej regulacji poczęć? (1968 r. z. 1, s. 31-52) omówił moralne aspekty stosowania pigułek antyowulacyjnych. Na początku artykułu autor wyjaśnił, czym są owe pigułki i jakie jest ich działanie. Następnie przedstawił różne stanowiska odnośnie do stosowania środków antyowulacyjnych, w tym opinie Kościoła katolickiego.

W tym też zeszycie J. Turowicz, w publikacji Antykoncepcja czy kształtowanie rodziny wedtug myśli Bożej? (s. 53-70), zajął się aktualną i żywo dyskutowaną kwestią regulacji poczęć. W artykule autor stwierdził, że w poszukiwaniu odpowiedzi na powyższy temat istotne jest ustalenie pierwszorzędnego celu małżeństwa w świetle Pisma Świętego, tradycji i nauki Kościoła.

W ostatnim w 1969 r. z. 4 B. Inlender w artykule Normy etyczne zawarte w encyklice „Humanae vitae” i ich uzasadnienie (s. 33-48) przedstawił naukę Kościoła na temat etyki małżeńskiej. Punktem wyjścia autora w przeprowadzanych badaniach była encyklika Pawła VI Humanae vitae. Inlender na początku rozprawy omówił naturę miłości małżeńskiej, która „ma być miłością ludzką, pełną, wierną, wyłączną oraz płodną" (s. 35). Następnie, odwołując się do encykliki Humanae vitae, przedstawił etyczną ocenę antykoncepcji, gdzie celem każdego aktu małżeńskiego powinno być przekazywanie życia.

W 1989 r. w z. 4 E. Kowalski w artykule Ocena moralna interwencji biomedycznych dotyczacych procesu przekazywania i początków życia ludzkiego (s. 45-59) analizował kwestie dotyczące życia ludzkiego, w tym biomedyczne ingerencje w proces przekazywania życia. Na początku autor przedstawia kryteria moralnej oceny interwencji 
biomedycznych, takich jak zapłodnienie in vitro. Napisał, że „kryterium sądu moralnego wyznacza przede wszystkim właściwa antropologia, tzn. właściwa koncepcja człowieka jako osoby ludzkiej” (s. 47).

Z kolei P. Bortkiewicz, w artykule Mentalność eutanatyczna $w$ świetle encykliki „Evangelium vitae” (1996 r. z. 3, s. 83-93) ocenił eutanazję w perspektywie nauczania Kościoła. Na początku autor przybliżył różne określenia zjawiska eutanazji, a także podał definicję papieża Jana Pawła II z encykliki Evangelium vitae. Bortkiewicz przedstawił też argumentację papieża w perspektywie nauczania Kościoła odrzucającego możliwość eutanazji.

\section{Kwestia odnowy teologii moralnej}

Wydaje się, że ostatnia część tematyczna jest najciekawsza i najbardziej nowatorska, gdyż pokazuje wysiłki polskich teologów moralistów w dostosowaniu przesłania moralnego do ówczesnych czasów. Zebrane rozprawy nie tylko opisują przyczyny kryzysu teologii moralnej, ale wskazują drogi odnowy. Wpisują się też w prowadzoną dyskusję wokół tożsamości teologii moralnej. Należy zauważyć, że inspiracją do napisania prac były wypowiedzi i dokumenty II Soboru Watykańskiego, w których zachęcano teologów do wyznaczania nowych kierunków badań i refleksji zarówno na polu teologii ogólnej jak i teologii moralnej. W tym przedziale naukowym wyróżnić należy takich autorów jak: S. Olejnik, S. Witek, J. Pryszmont, I. Mroczkowski i P. Góralczyk.

W 1952 r. ukazał się obszerny artykuł S. Olejnika pod tytułem Współczesne kierunki, zagadnienia i postulaty teologiczno-moralne (s. 66-114) będący odpowiedzią na krytyczną refleksję J. Woronieckiego na temat sytuacji teologii moralnej w Polsce. Autor rozprawy badał różne próby reformistyczne teologii moralnej z ostatniego półwiecza, przytaczając stanowiska ówczesnych moralistów. Wskazał na przykładzie różnych opracowań słabe strony teologii moralnej, do których zaliczył m.in. niepodejmowanie przez moralistów problematyki życia społecznego i gospodarczego czy posługiwanie się przestarzałą metodą kazuistyczną. Jednocześnie postulował, by teologia 
moralna poświęcała mniej miejsca problematyce grzechu, a więcej cnotom. Olejnik podkreślił potrzebę powrotu do idei naśladowania Chrystusa, gdyż, jak napisał, „teologia moralna musi rozpatrzeć znaczenie w życiu moralnym wzorów osobowych" (s. 89). Postulował, aby odnowiona teologia moralna bardziej akcentowała teologię łaski czy etykę społeczną. Zachęcał też, aby uprawiać ją w duchu personalizmu, wzorując się na moralistach francuskich.

Także w następnym artykule z 1954 r. zatytułowanym $O$ nowe drogi dla teologii moralnej (s. 575-596) S. Olejnik kontynuował dzieło reformy teologii moralnej. Na początku odniósł się do propozycji wybitnego moralisty J. Leclercqa, który w książce $O$ nauczaniu moralności chrześcijańskiej (1950 r.) wskazał pewne drogi naprawy teologii moralnej. Autor artykułu, podobnie jak Leclercq, był przekonany, że teologia moralna potrzebuje nowych inspiracji i rozwiązań. W dalszej części artykułu Olejnik polemizował z argumentami J. Woronieckiego, znanego profesora teologii moralnej, który opowiadał się za utrzymaniem dawnego modelu teologii moralnej opartym na kazuistyce i prawie. Olejnik napisał m.in.: „Trudno jest jednak zgodzić się z wnioskami, jakie z tego Recenzent wyprowadza" (s. 589), a dalej dodał: „Dlaczego ci, którzy tak pięknie marzą o odnowie teologii moralnej, marzeń swych nie ucieleśniają wkładem. Powinni przecież pisać podręczniki, nie postulować, ale realizować" (s. 595).

W 1960 r. S. Olejnik opublikował kolejny artykuł pod tytułem Problem wewnętrznej jedności struktury katolickiej etyki katolickiej (s. 33-56), w którym badał specyfikę teologii moralnej i jej związków z innymi dyscyplinami teologicznymi. Nadal poszukiwał tożsamości teologii moralnej, a jednocześnie jej odnowy i dostosowania do współczesnych czasów. Podkreślił, że choć istnieje jedna teologia, która zawiera różne dyscypliny teologiczne, w tym także teologia moralna, to są one ze sobą ściśle powiązane. Przypomniał, że dziedzina teologii moralnej wyodrębniła się z teologii dogmatycznej dopiero w XVII w. i proces ten trwa nadal. Olejnik badał uwarunkowania teologii moralnej, która według niego na przestrzeni historii zbytnio związała się z prawem, przyjmując z prawa kanonicznego podejście legalistyczne i minimalistyczne. W związku z tym, zainspirowany 
książką wybitnego moralisty niemieckiego B. Häringa (Das Gesetz Christi), proponował rozumienie moralności jako odpowiedzi człowieka na słowo Boże i budowania odpowiedzialności opartej na nauce Chrystusa. Zatem nie tyle prawo czy nawet Dekalog, ale naśladowanie Chrystusa winno stać się przedmiotem odnowy współczesnej teologii moralnej. Olejnik w uzasadnieniu propozycji chrystocentrycznej napisał: „W chrześcijańskim porządku działania żyć moralnie dobrze to znaczy stać się podobnym do Chrystusa, naśladować go w działaniu. Chrystus jest najwyższym, ale dającym się naśladować wzorem osobowym" (s. 42). Zatem teologia moralna w nowym wydaniu powinna być nauką o naśladowaniu Chrystusa.

W 1968 r. w z. 1 aż trzy artykuły poświęcono tematyce moralnej. Najpierw S. Smoleński w publikacji zatytułowanej Teologia moralna wobec potrzeb świata współczesnego: z moralnych aspektów Konstytucji pastoralnej „,Gaudium et spes” (s. 19-29) zajął się kwestią dostosowania zasad moralnych do współczesnych wyzwań społecznych. Na początku artykułu autor omówił nowe ujęcie antropologii chrześcijańskiej w dokumencie soborowym Gaudium et spes, podkreślającym nieporównywalną godność osoby ludzkiej. Napisał, że „godność osoby ludzkiej według nauki soborowej zasadza się przede wszystkim na wolności, czyli zdolności świadomego pójścia za dobrem i prawdą" (s. 21). Autor artykułu dostrzega więc konieczność wychowania chrześcijan do odpowiedzialności i dojrzałości moralnej w duchu nauki soborowej.

W kolejnym zeszycie „Collectanea Theologica” S. Witek w artykule zatytułowanym Zagadnienie źródet teologii moralnej (1969 z. 1, s. 17-34) zaznaczył, że teologia moralna powinna być nauką interdyscyplinarną i ,rozwijać ciągły dialog z rozmaitymi gałęziami nauki ludzkiej” (s. 23). Przekonywał, że tylko takie podejście pozwoli teologii moralnej odczytywać na nowo znaki woli Bożej w odniesieniu do współczesnego człowieka. Zatem według Witka teologia moralna powinna bardziej korzystać z dorobku filozofii, ksiąg pozachrześcijańskich czy literatury.

Następnie J. Pryszmont w artykule Wokół zagadnienia chrystocentryzmu w teologii moralnej (1970 r. z. 1, s. 13-32) zajął się ukazaniem 
wizji chrystocentrycznej w teologii moralnej. Autor zaznaczył, że teologia moralna potrzebuje orientacji chrystocentrycznej, czyli powrotu do Chrystusa jako źródła moralności chrześcijańskiej. Postulował, by teologia moralna ogniskowała się wokół osoby Chrystusa i Jego Ewangelii. Napisał, że „chrześcijańska nauka moralności nie jest tylko zestawem praw i norm (...), ale winna być przepowiadaniem Dobrej Nowiny o zbawieniu dokonanym przez Chrystusa" (s. 17). Zatem w teologii moralnej powinna dominować idea naśladowania Chrystusa.

W 1970 r. w z. 3 H. Juros przedstawił artykuł zatytułowany Chrześcijańska moralność relacji międzyosobowych (s. 63-74). Rozważania autora dotyczyły często podejmowanej po II Soborze Watykańskim krytyki teologii moralnej oraz wskazywania dróg reformy. Zwrócił uwagę, że „w odnowie teologii moralnej muszą być brane pod uwagę takie postulaty jak chrystocentryczne ujęcie etyki chrześcijańskiej, które godzi pozorną antynomię między teo- i antropocentryzmem, eklezjalny, sakramentalny i personalno-responsoryczny charakter tej etyki” (s. 65). Juros widział odnowę teologii moralnej przede wszystkim w filozofii dialogu i chrześcijańskim personalizmie, które akcentowały relacje wspólnotowe.

W 1972 r. W z. 2 ukazała się kolejna publikacja S. Olejnika pod tytułem Pluralizm teologiczny a jedność chrześcijańskiej moralności (s. 20-38), w której autor rozważał problem jedności wiary i pluralizmu teologicznego. W artykule badał uwarunkowania pluralizmu zarówno w ujęciu historycznym jak i w czasie współczesnym. Zaznaczył, że pluralizm moralny polega na zastosowaniu zasad ogólnych do konkretnych okoliczności. W końcowym fragmencie artykułu pokazał granice pluralizmu, zaznaczając, że „nieskrępowany pluralizm może wnieść w życie Kościoła pomieszanie języków, groźny stan wieży Babel” (s. 34).

Trzy lata później S. Olejnik na nowo podjął temat pluralizmu teologicznego (1975 r. z. 2, s. 5-18) w artykule Jedność wiary a pluralizm teologiczny. Poruszył w nim efekt kilkuletnich prac Międzynarodowej Komisji Teologicznej z 1972 r. na powyższy temat. Wówczas zapisano, że „szacunek dla autonomii wartości ludzkich i prawowitej 
odpowiedzialności na tym polu zakłada możliwości różnorodności analiz i okresowych opcji ze strony chrześcijan" (nr 15). Olejnik na podstawie powyższego dokumentu przedstawił stan badań odnośnie do jedności i pluralizmu w zakresie moralności chrześcijańskiej. Napisał, że „chodzi nie tylko o różnorodność przekonań moralnych, ale o odmienność w formułowaniu obiektywnych wskazań etycznych" (s. 15). Podkreślił, że pluralizm jest dopuszczalny w zakresie poszukiwania indywidualnych dróg prowadzących do Chrystusa czy w realizowaniu pewnych wartości ludzkich. Dodał też, że według św. Pawła pluralizm wynika przede wszystkim z wolnego działania człowieka.

W 1975 r. z. 4 pojawił się kolejny artykuł z cyklu prób reformowania teologii moralnej po II Soborze Watykańskim napisany przez F. Furgera i zatytułowany Odnowa teologii moralnej (s. 29-37). Autor zaznaczył, że zasadniczy kryzys teologii moralnej opartej na zbyt kazuistycznych wskazaniach został zażegnany, to jednak istnieje potrzeba dalszych prac nad jej rozwojem i przystosowaniem do wyzwań współczesnego świata. Podkreślił, że teologia moralna obrała właściwą orientację w społecznym ukierunkowaniu etyki chrześcijańskiej i badaniach interdyscyplinarnych, ale proces ten nie jest jeszcze zakończony. Należy zatem rozpatrywać problemy społeczno-moralne dotyczące gospodarki, środowiska czy pokoju. Według autora rozprawy postulat soborowy ubiblijnienia teologii moralnej domaga się szybszej realizacji i wdrożenia. Jak napisał Furger, „brak jeszcze wystarczająco daleko posuniętych studiów hermeneutycznych" (s. 33).

$\mathrm{Z}$ kolei J.-M. Aubert w artykule Czy jest miejsce dla moralności chrześcijańskiej? (1977 r. z. 3, s. 39-48) poruszył istotny problem narastającego napięcia między Kościołem i jego nauką, a postępem światowym. Autor zwrócił uwagę na ukształtowanie się nowego humanizmu opowiadającego się za nieskrepowaną wolnością i relatywizmem moralnym, jednoznacznie odrzucającego zasady moralne. Aubert przyznał, że do ówczesnego kryzysu przyczyniła się znacznie teologia moralna zbytnio akcentująca jurydyzm moralny i systemy kazuistyczne. Dlatego autor postulował odnowienie teologii moralnej 
przez zwrócenie uwagi na kwestie społeczne i podjęcie dialogu wobec współczesnych wyzwań.

W 1978 r. w z. 2 J. Piegsa w artykule Problematyka ustalania norm etycznych (s. 59-68) odniósł się do propozycji 60 naukowców, którzy na sympozjum w Jerozolimie domagali się zredagowania nowego kodeksu odnośnie do moralnej odpowiedzialności. Piegsa na początku artykułu nawiązał do ówczesnego kryzysu moralności, zauważając, że nie oznacza on kwestionowania wartości, ale że jest kryzysem sposobu przekazywania i uzasadniania norm moralnych. Napisał m.in., że ,ustalanie norm jest zadaniem trudnym, przy którym człowiek nie może ani postępować samowolnie, ani nie jest skazany na bierne wynajdywanie uprzednio danego, deterministycznego porządku" (s. 61). Piegsa podkreślił też, że należy odróżnić ogólne zasady od szczegółowych norm moralnych, gdzie zasady są pierwszorzędne, na czele z przykazaniem miłości.

W następnym zeszycie J. Pryszmont, zasłużony redaktor Biuletynu teologicznomoralnego, w artykule Wokół nowych ujęć problematyki teologicznomoralnej (1979 r. z. 4, s. 5-20) opisał aktualną sytuację teologii moralnej w Polsce. Napisał już we wstępie: „Rozwój myśli teologicznomoralnej w dobie posoborowej odznacza się niewątpliwie dużym dynamizmem. Świadczy o nim imponująca ilość nowych publikacji z tego zakresu pojawiających się na rynku księgarskim. Jeszcze bardziej potwierdzają to zmiany o charakterze merytorycznym, jakie dokonały się i stale się dokonują w uprawianiu teologii moralnej" (s. 5). Opisując stan teologii moralnej, zwrócił uwagę na rozległą tematykę w podejmowanych badaniach, do której trzeba zaliczyć kwestie: małżeństwa i rodziny, etyki seksualnej, sztucznego zapłodnienia, przeszczepów, eutanazji, pracy czy ochrony środowiska. Autor wskazywał również na interdyscyplinarność teologii moralnej, otwartej przede wszystkim na psychologię czy socjologię. Do plusów w rozwoju obecnej teologii moralnej zaliczył też proces ubiblijnienia, a także powiązania z dogmatyką. Pryszmont w posumowaniu stwierdził, że nastąpiło przesunięcie akcentu w teologii moralnej z ujęcia prawnego na rzecz personalistycznego, ze szczególnym podkreśleniem idei naśladowania Chrystusa. 
Później w 1982 r. w z. 2 także W. Skrzydlewski w obszernym artykule Sytuacja i perspektywy katolickiej teologii moralnej (s. 5-38) przedstawił kondycję teologii moralnej w perspektywie ostatnich piętnastu lat. Autor w rozprawie omówił pięć zasadniczych nurtów problemowych, które były badane przez teologów moralistów. Napisał, że „te główne nurty to radykalne teologie społeczne, teologia praw człowieka, spór o swoistość etyki chrześcijańskiej, permisywne tendencje w etyce seksualnej oraz poszukiwanie nowych zasad w teologii moralnej" (s. 5). Następnie skomentował poszczególne trendy, pokazując ich specyfikę i uwarunkowania. Na koniec wskazał możliwości przebudowy teologii moralnej.

Następnie I. Mroczkowski w publikacji Duchowość polskiego duszpasterza (1988 r. z. 1, s. 57-70) ocenił działalność polskiego kapłana. Powołując się na raport o stanie wiary J. Ratzingera, zwrócił uwagę, że kryzys Kościoła jest wynikiem słabości ludzi Kościoła, w tym przede wszystkim księży. Mroczkowski wskazał zarówno czynniki socjologiczne jak i religijne mające istotny wpływ na kryzys Kościoła. Do najważniejszych zaliczył: ateizm, sekularyzację, konsumpcjonizm, nieskuteczność katechezy, redukcję orędzia chrześcijańskiego czy zapoznanie grzechu. W dalszej części artykułu wskazał pewne propozycje w odniesieniu do współczesnych kapłanów.

W 1991 r. w z. 4 A. Marcol, w artykule Spowiednik wobec matżeństw niesakramentalnych (s. 107-118), opisał możliwości dopuszczenia do sakramentów małżonków żyjących w związkach niesakramentalnych. W swojej pracy nawiązał do trzech dokumentów Kościoła katolickiego: Litterae circulares Kongregacji Nauki Wiary (1973 r.), Adhortacji apostolskiej Familiaris consortio (nr 84) i Adhortacji apostolskiej Reconciliatio et paenitentia (nr 34). Autor podkreślił, że Kościół nie ma władzy rozwiązywania nieudanych małżeństw. Natomiast może zaproponować nie tyle przyjmowanie sakramentów, ile uczestniczenie w życiu Kościoła inaczej aniżeli przyjmowanie sakramentów. Marcol wymienił różne formy obecności w Kościele, takie jak: słuchanie słowa Bożego, modlitwa i udział we mszy św. (bez przyjmowania Komunii św.), gdyż „całe życie Kościoła ma charakter sakramentalny i każdy chrześcijanin w tej 
sakramentalności partycypuje" (s. 114). Na koniec stwierdził, że pewną propozycją dla małżeństw niesakramentalnych jest duszpasterstwo pozasakramentalne.

W kolejnym zeszycie z 1992 r. (z. 2) P. Góralczyk w artykule Główne nurty teologii moralnej po Vaticanum II (s. 57-69) już na początku napisał, że „Teologia moralna należy do tej dziedziny wiedzy, która jakby z natury swej domaga się ciągłej odnowy i nowej pogłębionej refleksji nad etycznymi zagadnieniami życia człowieka" (s. 57). Autor w rozprawie poszukiwał przede wszystkim dróg odnowy teologii moralnej, inspirując się postulatami II Soboru Watykańskiego. Przypomniał też główne postulaty soborowe odnośnie do teologii moralnej: ubiblijnienia, konieczności życia w łączności z Chrystusem oraz świadczenia miłości.

$$
* * *
$$

W długiej historii czasopisma „Collectanea Theologica” powstawały opracowania, dysertacje i studia naukowe bazujące nie tylko na twórczości teologów europejskich, ale stopniowo budujące podstawy niezależnej polskiej teologii. Dorobek tego pisma jest owocem prawie stuletniego poszukiwania tożsamości polskiej teologii, w tym teologii moralnej. W zasadzie problematyka moralna, która odnosiła się do istotnych i aktualnych wydarzeń czy wyzwań ówczesnych rzeczywistości, była poruszana od pierwszych zeszytów w stuletnim czasie ukazywania się pisma naukowego. W głównym nurcie badanej problematyki był wyraźnie widoczny wysiłek polskich teologów moralistów w określeniu zarówno przyczyn kryzysu jak i propozycji reform czy odnowy. Prześledzenie poruszanej tematyki moralnej na przestrzeni jednego wieku, zarówno przed jak i po II Soborze Watykańskim, pokazuje wieloaspektowość poruszanych zagadnień, a także ważne zmiany zachodzące w uprawianiu teologii moralnej. Zatem analizowane zagadnienia z zakresu teologii moralnej były odbiciem dyskusji i polemik toczących się zarówno w kraju jak i zagranicą nie tylko w środowiskach teologicznych. 
Efektem badań polskich teologów moralistów publikujących w „Collectanea Theologica” były rozprawy i dysertacje, w których podejmowano aktualną problematykę moralną w perspektywie interdyscyplinarnej, zarówno nauk teologicznych, jak i empirycznych. W powyższym opracowaniu obszerny materiał badawczy został podzielony na osiem bloków tematycznych: historyczno-moralny (22), biblijno-moralny (6), filozoficzno-moralny (26), psychologiczno-moralny (7), pastoralno-moralny (9), katolickiej nauki społecznej (21), biomedyczno-moralny (6) i kwestii odnowy teologii moralnej (17). Łącznie powstało 114 artykułów, w których zbadano wieloaspektowość poruszanych zagadnień.

\section{ks. Krzysztof KIETLIŃSKI}

Słowa kluczowe: publikacje moralne; Collectanea Theologica; polscy teolodzy moraliści; interdyscyplinarność teologii moralnej

Keywords: moral publications; Collectanea Theologica; Polish moral theologians; interdisciplinarity of moral theology

\section{Moral Issues in the Hundred-Year History of the Quarterly "Collectanea Theologica"}

Summary

The aim of the publication is to analyse scholarly articles in the field of moral theology in the hundred-year history of "Collectanea Theologica". It should be noted that this Polish scholarly quarterly has been published since 1920, and until 1930 it was published under the title "Przegląd Teologiczny". The choice of subjects of theological and moral disputes was strongly influenced by the debates and decisions of the Second Vatican Council, which inspired theologians to study contemporary challenges and look for ways of renewal for individual theological disciplines. The results of their research were the articles in which they analysed current moral issues from an interdisciplinary perspective of both theological and empirical sciences. For this reason, the extensive research material can be 
divided into eight thematic blocks: historical-moral (22 articles), biblicalmoral (6), philosophical-moral (26), psychological-moral (7), pastoral-moral (9), Catholic social teaching (21), biomedical-moral (6) and the matters to the renewal of moral theology (17). Altogether, in the years 1920-2020, 114 theological-moral articles were published in which such multifaceted issues were examined. 